\title{
Article \\ Utilization of Corn Cob Ash as Fine Aggregate and Ground Granulated Blast Furnace Slag as Cementitious Material in Concrete
}

\author{
Naraindas Bheel ${ }^{1}$ (D), Montasir Osman Ahmed Ali ${ }^{1}$, Yue Liu ${ }^{2, *(D)}$, T. Tafsirojjaman ${ }^{3}$ (D), Paul Awoyera ${ }^{4}$ (D), \\ Nadhim Hamah Sor ${ }^{5,6}$ and Lenin Miguel Bendezu Romero ${ }^{7}$
}

1 Department of Civil and Environmental Engineering, Universiti Teknologi PETRONAS, Bandar Seri Iskandar, Tronoh 31750, Perak, Malaysia; naraindas04@gmail.com (N.B.); montasir.ahmedali@utp.edu.my (M.O.A.A.)

2 The Key Laboratory of Urban Security and Disaster Engineering of Ministry of Education, Beijing University of Technology, 100 Pingleyuan, Beijing 100124, China

3 Centre for Future Materials (CFM), School of Civil Engineering and Surveying, University of Southern Queensland, Toowoomba, QLD 4350, Australia; tafsirojjaman@usq.edu.au

4 Department of Civil Engineering, Covenant University, Ota 112233, Nigeria; paul.awoyera@covenantuniversity.edu.ng

5 Civil Engineering Department, University of Garmian, Kalar 46021, Iraq; nadhim.abdulwahid@garmian.edu.krd

6 Department of Civil Engineering, Harran University, Sanlıurfa 63510, Turkey

7 Universidad Ricardo Palma, Lima 1801, Peru; lenin.bendezu@urp.edu.pe

* Correspondence: yliu@bjut.edu.cn; Tel.: +86-178-1238-7863

check for

updates

Citation: Bheel, N.; Ali, M.O.A.; Liu, Y.; Tafsirojjaman, T.; Awoyera, P.; Sor, N.H.; Bendezu Romero, L.M.

Utilization of Corn Cob Ash as Fine Aggregate and Ground Granulated Blast Furnace Slag as Cementitious Material in Concrete. Buildings 2021, 11, 422. https://doi.org/10.3390/ buildings11090422

Academic Editor: Abdelhafid Khelidj

Received: 26 August 2021

Accepted: 17 September 2021

Published: 21 September 2021

Publisher's Note: MDPI stays neutra with regard to jurisdictional claims in published maps and institutional affiliations.

Copyright: (c) 2021 by the authors. Licensee MDPI, Basel, Switzerland. This article is an open access article distributed under the terms and conditions of the Creative Commons Attribution (CC BY) license (https:// creativecommons.org/licenses/by/ $4.0 /)$.

\begin{abstract}
Cementitious and recycled materials that have the potential to improve various properties of concrete have attracted the attention of many researchers recently. Different types of cementitious and recycled materials seem to possess certain unique properties to change cement concrete. This experimental study aims to investigate the impact of ground granulated blast furnace slag (GGBFS) and corn cob ash (CCA) as a partial replacement material for Portland cement (PC) and fine aggregate (FA), respectively, on fresh and hardened concrete properties, as well as the embodied carbon of concrete. The concrete mix was blended with $5-20 \%$ of GGBFS and $10-40 \%$ of corn cob ash, both individually and combined. A total of 300 concrete specimens were made to achieve the targeted strength of $25 \mathrm{MPa}$ at a 0.50 water/cement ratio and cured at 28 days. It is observed that the workability of fresh concrete is lowered as the dosages of GGBFS and CCA increase in the mixture. Moreover, the compressive and split tensile strengths are augmented by $10.94 \%$ and $9.15 \%$, respectively, at $10 \%$ of GGBFS by the weight of PC at 28 days. Similarly, the compressive and split tensile strengths are augmented by $11.62 \%$ and $10.56 \%$, respectively, at $30 \%$ of CCA by the weight of FA at 28 days. Moreover, the combined use of $10 \%$ of GGBFS as a cementitious ingredient along with $30 \%$ of fine aggregate replaced with CCA in concrete provides the highest compressive and splitting tensile strength, with $16.98 \%$ and $13.38 \%$ at 28 days, respectively. Furthermore, the density and water absorption of concrete were reduced with increasing dosages of GGBFS and FA in concrete at 28 days. In addition, the embodied carbon and energy were also reduced as the replacement content of GGBFS along with CCA increased in concrete. It is concluded that 10\% of GGBFS and 30\% of CCA are the optimum percentages for structural applications to reduce the use of cement as well as the cost of the project.
\end{abstract}

Keywords: concrete; GGBFS; CCA; replacement; fresh and hardened concrete; reduce embodied carbon

\section{Introduction}

The improvement of hardened properties coupled with the capability to produce them in various forms have resulted in concrete, which is used mostly as a building material 
around the world [1]. The growth of the world's population and the process of urbanization have enhanced the usage of this material. The huge demand for concrete for commercial purposes has led to consequential impacts on the atmosphere due to the adverse effect of Portland cement (PC) production [2,3]. Changes in the composition of the atmosphere and subsequent climate change affect the mechanical properties of grout and concrete [4,5]. It is estimated that the manufacturing of PC accounts for around $8 \%$ of the world's carbon emissions in the atmosphere [6-9].

This high carbon footprint can be associated with the huge amount of energy consumption in the manufacturing process for PC and the release of carbon dioxide as a product that influences the environment. Thus, the utilization of various types of waste materials by partially replacing PC in concrete is significantly important to reduce such types of adverse effects on the environment. Different types of waste materials in various forms of ash or powder have been utilized in the partial replacement of PC in the mixture of concrete [10]. The partial replacement materials are primarily silica fume (SF) [11], coconut shell ash (CSA) [12], ground granulated blast furnace slag (GGBFS) [13], corn cob ash (CCA) [14], metakaolin (MK) [15], sugarcane bagasse ash (SCBA) [16], fly ash (FA) [17], groundnut shell ash (GSA) [18], etc.

Moreover, GGBFS is acquired in the form of waste materials. Its chemical composition is similar to that of PC, which comprises about $45 \%$ calcium oxide and around $35-45 \%$ silicon dioxide, and is available worldwide [19-24]. Therefore, it can be used as a PC replacement in concrete and decrease carbon dioxide emissions [25-27]. There are many studies on concrete blended with GGBFS as a cementitious material. According to Cervantes and Roesler [28], adding GGBFS ingredients as a PC replacement in concrete increased the compressive and flexural strengths of concrete at 28 days. Karri et al. [29] investigated concrete made of M20 and M40 grade containing 30\% to 50\% of GGBFS as a PC replacement. It was observed that the inclusion of GGBFS as a cementitious material in the mixture improved the split tensile, compressive, and flexural strengths of the hardened concrete at 28 days. Malagavelli and Rao [30] studied the characteristic strength of concrete made of M30 grade intermingled with GGBFS as a cementitious material and crushed dust as a sand replacement. It was perceived that the addition of $30 \%$ crushed dust to replace sand in the mixture could increase the compressive and tensile strengths by $8 \%$ and $1.83 \%$ at 28 days, respectively. Moreover, the hardened concrete was amplified as the range of GGBFS by the weight of PC increased in the mixture. Rughooputh et al. [31], Cahvani and Rusdianto [32], and Raman and Krishnan [33] described that the usage of 40-50\% GGBFS as a cementitious material provided the maximum compressive strength of the mixture.

Moreover, GGBFS can increase the impermeability, corrosion resistance, and sulfate resistance of concrete [34-36]. By taking these characteristics into account, it is possible to boost the service life of concrete structures and decrease maintenance costs. The high quantity of GGBFS in the ecological environment used to replace cement leads to the fact that concrete can use not only waste but also protect natural resources and energy consumption $[37,38]$.

Natural sand is another main component of concrete, and it is applied as a fine aggregate, which also distresses natural resources. The widening consumption of fine river sand aggregates will lead to a deterioration of riverbeds, a reduction in groundwater levels, erosion of riverbed lands, and the destruction of bridges, which may hinder a country's sustainable development. Therefore, innovating suitable material to use as a substitute for PC and natural aggregates is important. In addition, the continuous growth of agricultural and industrial wastes is increasing environmental pollution and distresses. Therefore, the usage of corn cob ash (CCA) as a fine aggregate replacement in concrete serves to reduce the above detrimental distresses. Corn cob, which may be processed into corn cob ash (CCA) and utilized as a fine aggregate replacement in concrete, is a promising waste product. Currently, the United States and other countries generate around 50 million tons of corn per annum $[39,40]$. This large amount of corn generates an approximately equal production of corn cob. Therefore, the inclusion of these waste resources into concrete mixtures will also 
support handling the waste effectively while producing an alternative to fine aggregate in concrete mixtures. Ash has low economic value; thus, instead of dumping it in a landfill, which will lead to environmental pollution, utilizing it as a building material will reap an enormous benefit. Due to the silica component in pozzolana reacting with free lime discharged throughout PC hydration [41], extra calcium silicate hydrate (CSH) is produced, which improves the hardened properties of concrete. Thus, most previous studies were performed on concrete blended with CCA as a PC replacement in concrete. According to Desai [42], 10\% of PC replaced with CCA could increase compressive, split tensile, and flexural strengths by $5.90 \%, 5.67 \%$, and $5.92 \%$ after 90 days, respectively. Adesanya and Raheem [43] reported that the slump declined as the CCA content increased in the concrete mixture. Adesanya and Raheem [44] also described that the concrete was made of a 1:1.5:3 mix proportion blended with CCA as a PC replacement for determining the water absorption, permeability, and weight loss. The results showed that the use of CCA up to $15 \%$ as a cementitious material reduced water absorption, permeability, and weight loss of concrete. Owolabi, Oladipo, and Popoola [45] conducted experimental work on concrete with CCA as a PC replacement. They indicated that the increase in CCA in the mixture lowered the workability of the concrete. Moreover, $5 \%$ of PC replaced with CCA in the mixture recorded the best outcome, with a crushing strength of $21.44 \mathrm{MPa}$ at 28 days.

According to the literature, many investigations were explored using GGBFS and CCA as PC replacements in concrete. However, there are very limited works conducted on concrete with the inclusion of CCA as a fine aggregate replacement material and no experimental work was performed on concrete with the inclusion of various dosages of PC replaced with GGBFS along with fine aggregate replaced with CCA. Therefore, our main objective is to analyze the fresh and hardened properties and embodied carbon of concrete using various levels of GGBFS as a PC replacement and CCA as a fine aggregate replacement, both separate and together in concrete mixtures.

\section{Materials and Methods}

\subsection{Materials}

The ground granulated blast furnace slag (GGBFS) was attained from a steel mill with prior approval. After collecting it, GGBFS was dried under atmospheric conditions for $24 \mathrm{~h}$. The dried GGBFS was passed through the \#300 sieve to eliminate the unwanted atoms, and then used as a PC replacement ingredient in the mixture. The corn cob was collected near Hyderabad, Sindh, Pakistan, and then it was burnt under an uncontrolled temperature arrangement for five hours to convert it into corn cob ash (CCA). After obtaining the ash, it was sieved through the \#4 sieve to remove huge particles, and then the sieved ash was utilized as a replacement for sand components in the mixture. The Portland cement (PC) was collected from Hyderabad, Sindh, and it was applied to the concrete mixture as a binding ingredient. The oxide compositions of PC, GGBFS, and CCA are shown in Table 1 and the images of CCA and GGBFS are shown in Figure 1. Furthermore, crushed stone was utilized for this research work as a coarse aggregate (CA), with a size of $20 \mathrm{~mm}$, and hill sand was utilized in this experimental study as a fine aggregate (FA), which passed through the \#4 sieve. These aggregates were acquired from Hyderabad, Sindh as shown in Figure 2. The physical properties of the aggregates are given in Table 2. In addition, potable water was utilized to carry out this experimental work.

Table 1. Oxide compositions of PC, GGBFS, and CCA.

\begin{tabular}{|c|c|c|c|c|c|c|c|}
\hline \multirow{2}{*}{ Binder } & \multicolumn{6}{|c|}{ Oxides (\%) } & \multirow{2}{*}{$\begin{array}{c}\text { Physical Property } \\
\text { Specific Gravity }\end{array}$} \\
\hline & $\mathrm{SiO}_{2}$ & $\mathrm{Al}_{2} \mathrm{O}_{3}$ & $\mathrm{Fe}_{2} \mathrm{O}_{3}$ & $\mathrm{CaO}$ & $\mathrm{Na}_{2} \mathrm{O}$ & $\mathrm{SO}_{3}$ & \\
\hline $\mathrm{CCA}$ & 67.23 & 6.34 & 5.33 & 10.75 & 0.37 & 1.04 & 2.54 \\
\hline GGBFS & 37.22 & 10.37 & 1.23 & 35.66 & 0.23 & 0.34 & 2.25 \\
\hline PC & 20.78 & 5.11 & 3.17 & 60.22 & 0.18 & 2.86 & 3.13 \\
\hline
\end{tabular}




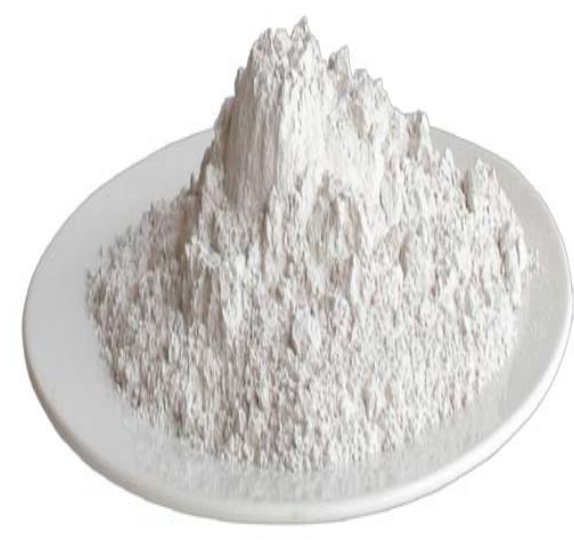

(a)

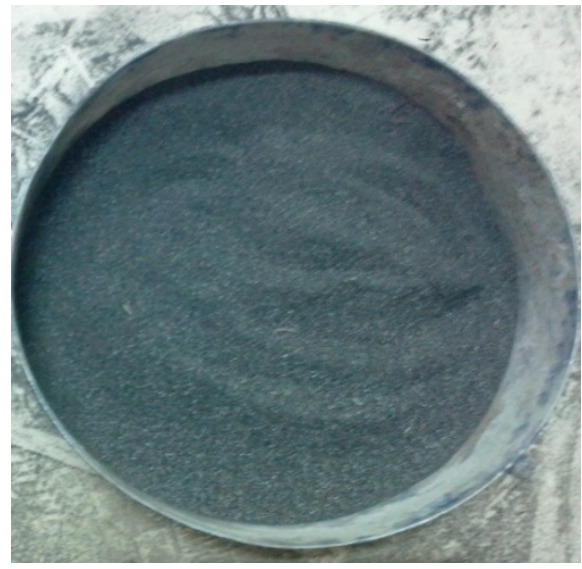

(b)

Figure 1. (a) Ground granulated blast furnace slag; (b) corn cob ash.

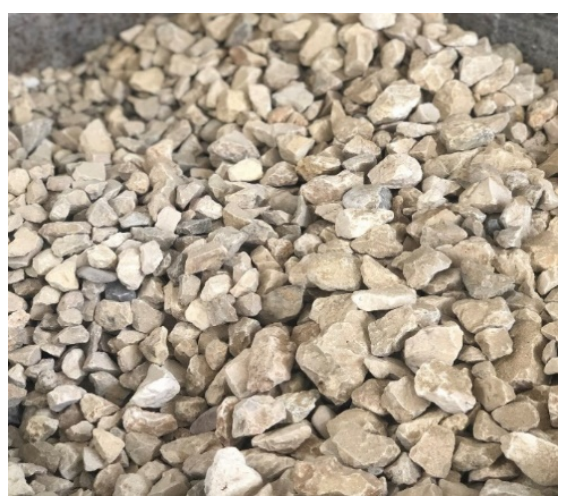

(a)

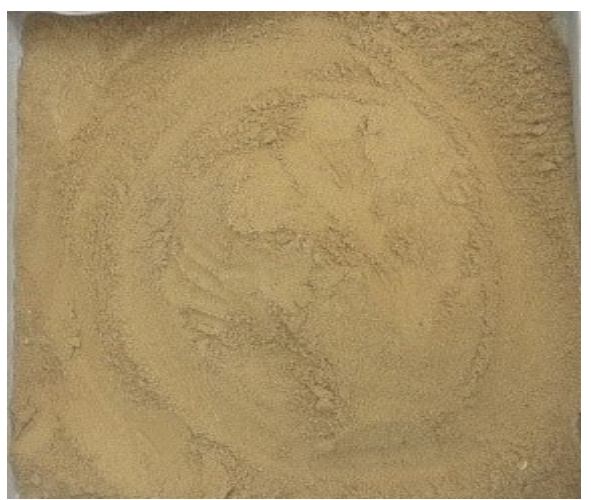

(b)

Figure 2. (a) Coarse aggregate; (b) fine aggregate.

Table 2. Properties of fine and coarse aggregates.

\begin{tabular}{ccc}
\hline Property & Fine Aggregate & Coarse Aggregate \\
\hline Specific Gravity & 2.66 & 2.71 \\
\hline Bulk Density $\left(\mathrm{kg} / \mathrm{m}^{3}\right)$ & 1920 & 1680 \\
\hline Fineness Modulus & 2.25 & - \\
\hline Water Absorption $(\%)$ & 1.32 & 0.69 \\
\hline
\end{tabular}

\subsection{Experimental Program}

This experimental work explored the fresh (slump), physical (water absorption and density), and hardened properties (splitting tensile and compressive strength) of concrete mixtures blended with $0-20 \%$ GGBFS as a replacement for PC and 10-40\% CCA as a sand replacement. We also tested the combined usage of GGBFS as a replacement for PC and CCA as a replacement of sand in the concrete mixture. A total of 300 concrete specimens were made to achieve the targeted strength of $25 \mathrm{MPa}$ and cured at 28 days. Moreover, 25 mixtures were prepared. One concrete mixture was prepared with PC only, four mixtures were prepared with the inclusion of 5-20\% GGBFS as the cementitious ingredient, and four mixtures were prepared with $10-40 \%$ CCA to replace the fine aggregate. Other concrete mixtures were made combining GGBFS as a PC replacement and CCA as a fine aggregate replacement. Table 3 shows the mix designs adopted for concrete production. 
Table 3. Designs of the mixtures.

\begin{tabular}{|c|c|c|c|c|c|c|c|c|c|c|}
\hline \multirow{2}{*}{ Mix ID } & \multicolumn{2}{|c|}{$\begin{array}{c}\text { Binding Material } \\
(\%)\end{array}$} & \multicolumn{2}{|c|}{$\begin{array}{c}\text { FA Content } \\
(\%)\end{array}$} & \multicolumn{6}{|c|}{ Quantity of Ingredients Required to Produce $1 \mathrm{~m}^{3}$ Concrete $(\mathrm{kg})$} \\
\hline & PC & GGBFS & CCA & FA & PC & GGBFS & FA & CCA & CA & Water \\
\hline $\mathrm{CM}$ & 100 & 0 & 0 & 100 & 346 & 0 & 564 & 0 & 940 & 173 \\
\hline GGBFS5 & 95 & 5 & 0 & 100 & 328.7 & 17.30 & 0 & 0 & 940 & 173 \\
\hline GGBFS10 & 90 & 10 & 0 & 100 & 311.4 & 34.60 & 0 & 0 & 940 & 173 \\
\hline GGBFS15 & 85 & 15 & 0 & 100 & 294.1 & 51.90 & 0 & 0 & 940 & 173 \\
\hline GGBFS20 & 80 & 20 & 0 & 100 & 276.8 & 69.20 & 0 & 0 & 940 & 173 \\
\hline CCA10 & 100 & 0 & 10 & 90 & 346 & 0 & 507.60 & 56.40 & 940 & 173 \\
\hline CCA20 & 100 & 0 & 20 & 80 & 346 & 0 & 451.20 & 112.8 & 940 & 173 \\
\hline CCA30 & 100 & 0 & 30 & 70 & 346 & 0 & 394.80 & 169.2 & 940 & 173 \\
\hline CCA40 & 100 & 0 & 40 & 60 & 346 & 0 & 338.40 & 225.6 & 940 & 173 \\
\hline GGBFS5CCA10 & 95 & 5 & 10 & 90 & 328.7 & 17.30 & 507.60 & 56.40 & 940 & 173 \\
\hline GGBFS5CCA20 & 95 & 5 & 20 & 80 & 328.7 & 17.30 & 451.20 & 112.8 & 940 & 173 \\
\hline GGBFS5CCA30 & 95 & 5 & 30 & 70 & 328.7 & 17.30 & 394.80 & 169.2 & 940 & 173 \\
\hline GGBFS5CCA40 & 95 & 5 & 40 & 60 & 328.7 & 17.30 & 338.40 & 225.6 & 940 & 173 \\
\hline GGBFS10CCA10 & 90 & 10 & 10 & 90 & 311.4 & 34.60 & 507.60 & 56.40 & 940 & 173 \\
\hline GGBFS10CCA20 & 90 & 10 & 20 & 80 & 311.4 & 34.60 & 451.20 & 112.8 & 940 & 173 \\
\hline GGBFS10CCA30 & 90 & 10 & 30 & 70 & 311.4 & 34.60 & 394.80 & 169.2 & 940 & 173 \\
\hline GGBFS10CCA40 & 90 & 10 & 40 & 60 & 311.4 & 34.60 & 338.40 & 225.6 & 940 & 173 \\
\hline GGBFS15CCA10 & 85 & 15 & 10 & 90 & 294.1 & 51.90 & 507.60 & 56.40 & 940 & 173 \\
\hline GGBFS15CCA20 & 85 & 15 & 20 & 80 & 294.1 & 51.90 & 451.20 & 112.8 & 940 & 173 \\
\hline GGBFS15CCA30 & 85 & 15 & 30 & 70 & 294.1 & 51.90 & 394.80 & 169.2 & 940 & 173 \\
\hline GGBFS15CCA40 & 85 & 15 & 40 & 60 & 294.1 & 51.90 & 338.40 & 225.6 & 940 & 173 \\
\hline GGBFS20CCA10 & 80 & 20 & 10 & 90 & 276.8 & 69.20 & 507.60 & 56.40 & 940 & 173 \\
\hline GGBFS20CCA20 & 80 & 20 & 20 & 80 & 276.8 & 69.20 & 451.20 & 112.8 & 940 & 173 \\
\hline GGBFS20CCA30 & 80 & 20 & 30 & 70 & 276.8 & 69.20 & 394.80 & 169.2 & 940 & 173 \\
\hline GGBFS20CCA40 & 80 & 20 & 40 & 60 & 276.8 & 69.20 & 338.40 & 225.6 & 940 & 173 \\
\hline
\end{tabular}

\subsection{Testing Methods}

In the concrete mixer, the dry constituents for every design mix were dry mixed together to form a homogeneous mix, and then the required amount of water was slowly added. Workability was evaluated once a sufficiently homogeneous wet mix was generated, and then the mixture was poured into the molds. A vibrating table was used to assure proper compaction, and the upper surface of the molds was then enclosed with a plastic bag to prevent surface cracking and shrinkage. The molds were stored for $24 \mathrm{~h}$ before being demolded and then placed in a curing tank for 28 days before being tested. Various tests were carried out to investigate the combined effect of GGBFS by the weight of PC and CCA by the weight of FA on the characteristics of concrete.

\subsubsection{Slump Test}

We performed slump tests on 25 mixtures of fresh concrete, incorporating several replacement levels of PC with GGBFS and various replacement levels of fine aggregate with CCA, both individually and combined, while conforming to code BS EN 12350-2 [46]. 


\subsubsection{Mechanical Properties of Concrete}

We tested the water absorption and dry density of the hardened concrete specimens made with the addition of various ratios of GGBFS as a PC replacement and CCA as an FA replacement, both individually and combined, while following BS 1881 [47] and BS EN 12390-7 [48] procedures, respectively. We tested the compressive strength of concrete cubes $(100 \mathrm{~mm} \times 100 \mathrm{~mm} \times 100 \mathrm{~mm})$ prepared with different levels of PC replaced with GGBFS and FA partially replaced with CCA, both separately and together, while conforming to the BS EN 12390-3 [49] code practice. In the same way, split tensile strength was attained for cylindrical samples $(200 \mathrm{~mm} \times 100 \mathrm{~mm}$ ) mixed with several levels of PC replaced with GGBFS and FA replaced with CCA, both individually and combined, under the BS EN 12390-6 [50] code practice. The fresh concrete and hardened concrete specimens were then tested, as shown in Figure 3a-d.

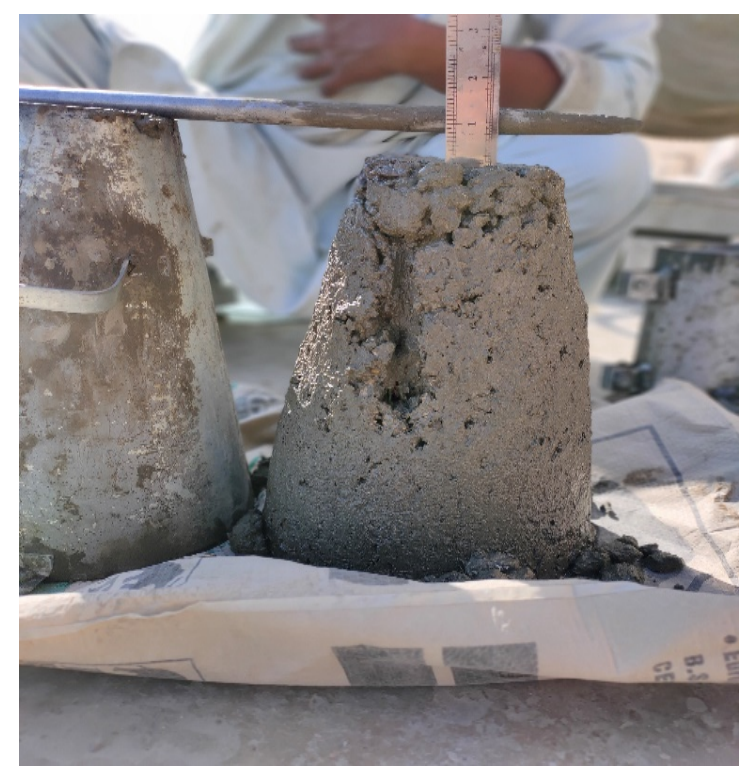

(a)

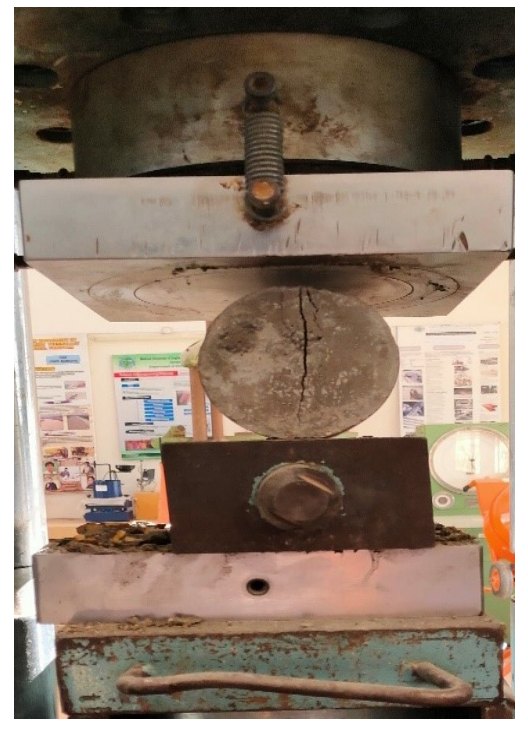

(c)

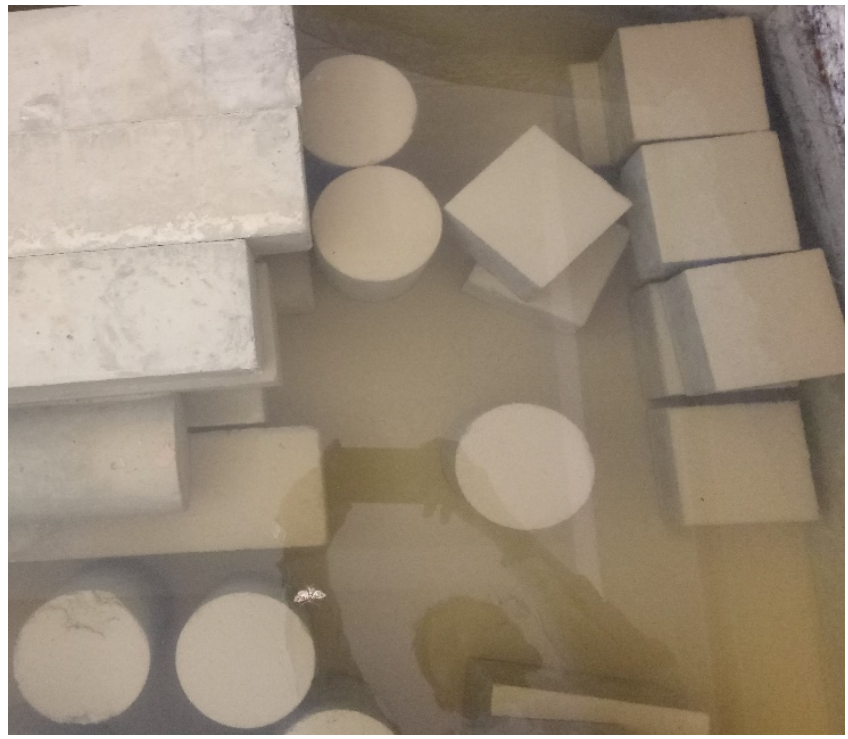

(b)

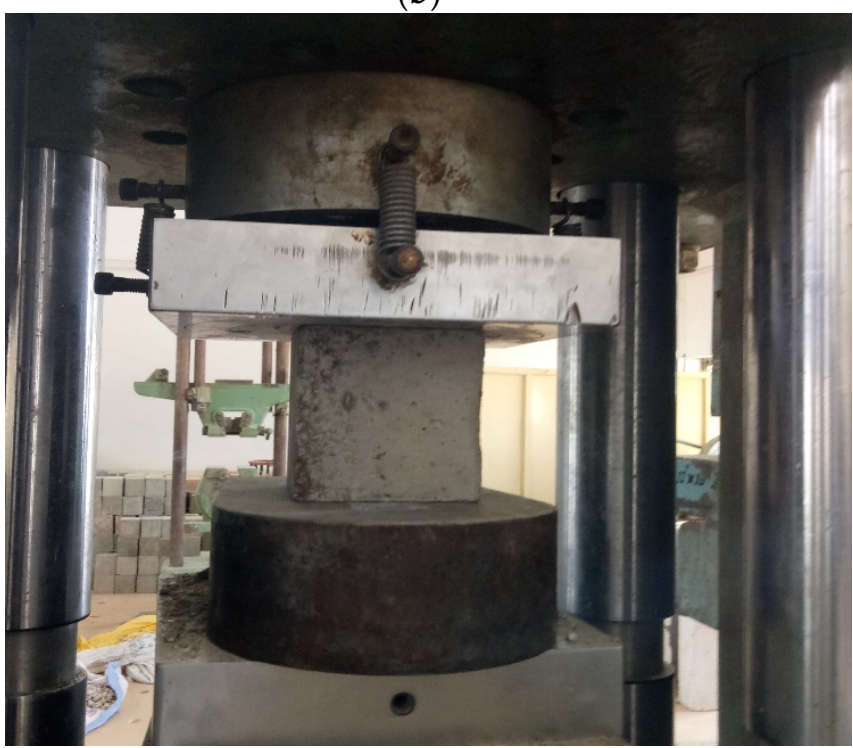

(d)

Figure 3. Experimental tests set-up: (a) slump test; (b) water curing tank; (c) split tensile strength test; (d) compressive strength test. 


\section{Results and Discussions}

\subsection{Slump Test}

The properties of concrete that govern the ease and homogeneity with which it can be mixed, placed, consolidated, and finished are known as workability. Figure 4 illustrates the workability of the fresh mixture incorporating various percentages of GGBFS as a PC replacement and CCA as an FA replacement. The slump levels are $12.50 \%, 26.78 \%, 35.71 \%$, and $51.78 \%$ with GGBFS levels of $5 \%, 10 \%, 15 \%$, and $20 \%$, respectively. The slump levels are $17.86 \%, 32.14 \%, 44.64 \%$, and $51.46 \%$ with CCA levels of $10 \%, 20 \%, 30 \%$, and $40 \%$. Both sets of slump levels are lower as compared to concrete made of PC only. Slump declines with the growth in the quantity of GGBFS by the weight of PC and FA replaced with CCA. A related study conducted by Bheel et al. [51] found that the workability of concrete declined with the replacement of PC with GGBFS and metakaolin was increased in the mixture. Bheel et al. [52] also documented that the use of fine aggregate partially replaced with WSA reduced the workability of concrete.

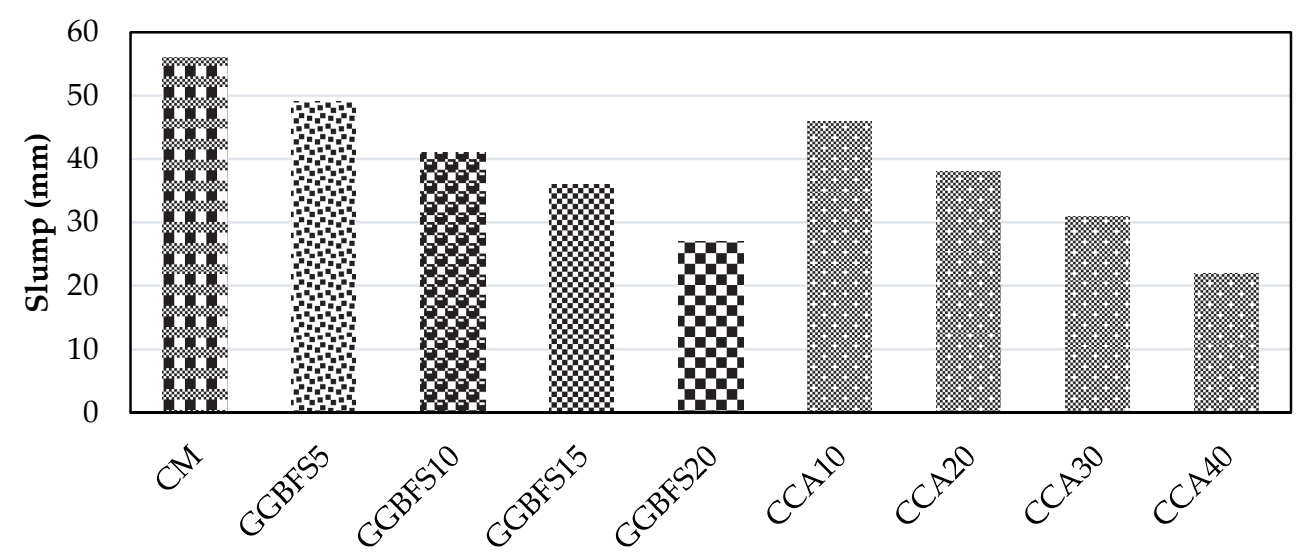

\section{GGBFS and CCA Content}

Figure 4. Slag slump tests of fresh concrete containing GGBFS and CCA.

Similarly, the utilization of coal bottom ash by the weight of FA decreased the flow of fresh concrete, according to Bheel et al. [53]. However, Figure 5 shows that the workability of fresh concrete is measured with the inclusion of GGBFS as a cementitious material and CCA as a replacement for sand. The best workability is recorded as being $56 \mathrm{~mm}$ with the accumulation of PC only. The lowest workability is noted as being $21.18 \mathrm{~mm}$ with GGBFS20CCA40 as a PC and FA replacement in concrete. It can be perceived that the slump dropped with the accumulation of GGBFS by the weight of PC and CCA as a sand replacement together in the mixture. The decline in workability is associated with the porous GGBFS and CCA particles, which absorb more water when their percentages increase in the concrete mixture. This research work is related to that of Bheel et al. [54], where the slump declined as MHA replaced PC and WSA replaced sand. Related investigations by Bheel et al. [53] found that the increased replacement of PC with RHA and sand with coal bottom ash resulted in lower workability of fresh concrete. Comparable investigations were explored by Keerio et al [55]. 


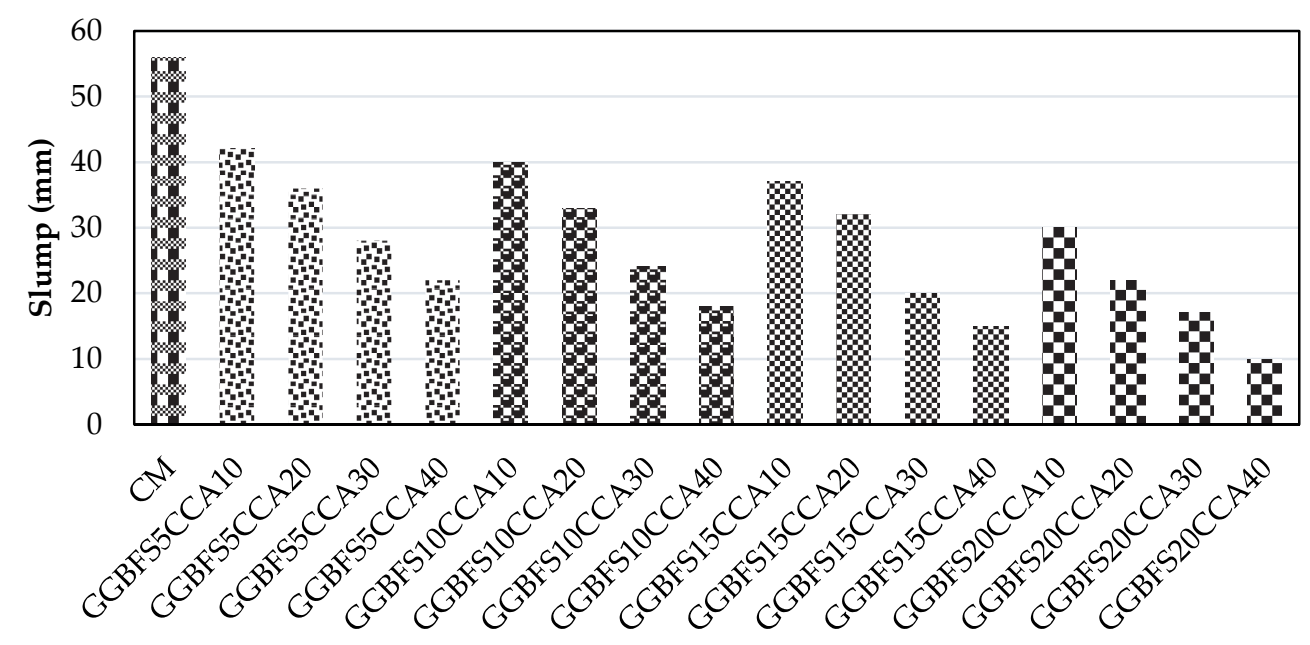

\section{GGBFS and CCA Content}

Figure 5. Slump tests of fresh concrete blended with GGBFS along with CCA.

\subsection{Water Absorption}

We performed water absorption tests on the specimens made of concrete with separate additions of GGBFS as a PC replacement and CCA as an FA replacement at 28 days, as displayed in Figure 6. The water absorption levels are 3.56\%, 2.98\%, 2.67\%, and 2.38\% when PC is replaced with GGBFS at levels of $5 \%, 10 \%, 15 \%$, and $20 \%$, respectively, and $3.45 \%, 2.92 \%, 2.53 \%$, and $2.15 \%$ when FA is replaced by CCA at levels of $10 \%, 20 \%, 30 \%$, and $40 \%$ at 28 days, respectively, which are lower compared to a concrete mix prepared with PC only. The outcomes reveal that when the replacement of PC with GGBFS and sand with CCA increases in concrete, there is a reduction in the concrete's water absorption. Comparable research was explored by Bheel et al. [54], where the increasing usage of MHA as a replacement of PC caused a decline in the water absorption of concrete. Related work was conducted by Keerio et al. [55], who found that water absorption plummeted as the percentage of glass powder as a replacement of FA increased in concrete. However, specimens prepared with the collective usage of GGBFS as a PC replacement and CCA as a fine aggregate replacement were utilized for water absorption at 28 days, as presented in Figure 7. The results of optimum water absorption are noted as being $3.88 \%$, and the lowest value is calculated as being $1.48 \%$ using GGBFS20CCA 40 as a replacement for PC, and fine aggregate replacement components in concrete are consistently lower as compared to concrete made with PC only at 28 days. The outcome shows that the water absorption of hardened concrete declines with the addition of GGBFS as a cementitious material along with CCA as a fine aggregate replacement. This drop in water absorption is due to the finest particles of GGBFS and CCA, which cover the remaining micro-porous materials left by other components of concrete. This work is related to that of Bheel et al. [53], who found that the water absorption declined with the increasing replacement of PC with RHA and of sand with coal bottom ash. A similar study by Keerio et al. [55] concluded that the increasing replacement of PC with silica fume and FA with glass powder reduces the water absorption of concrete. 


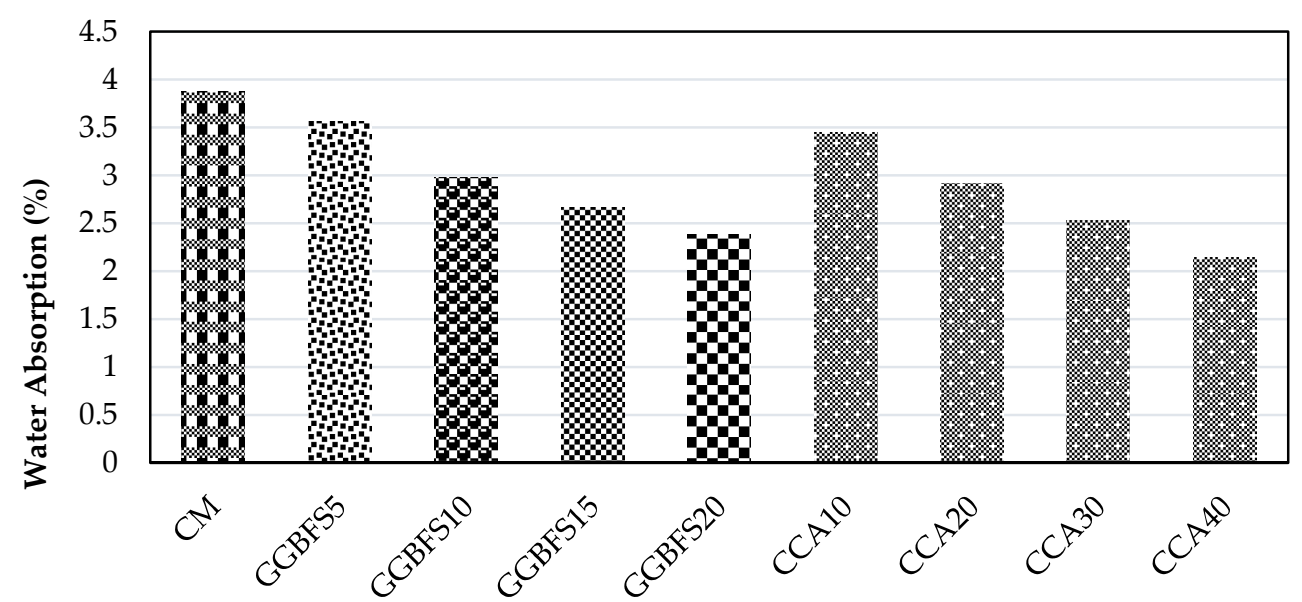

GGBFS and CCA Content

Figure 6. Water absorption of concrete containing GGBFS and CCA.

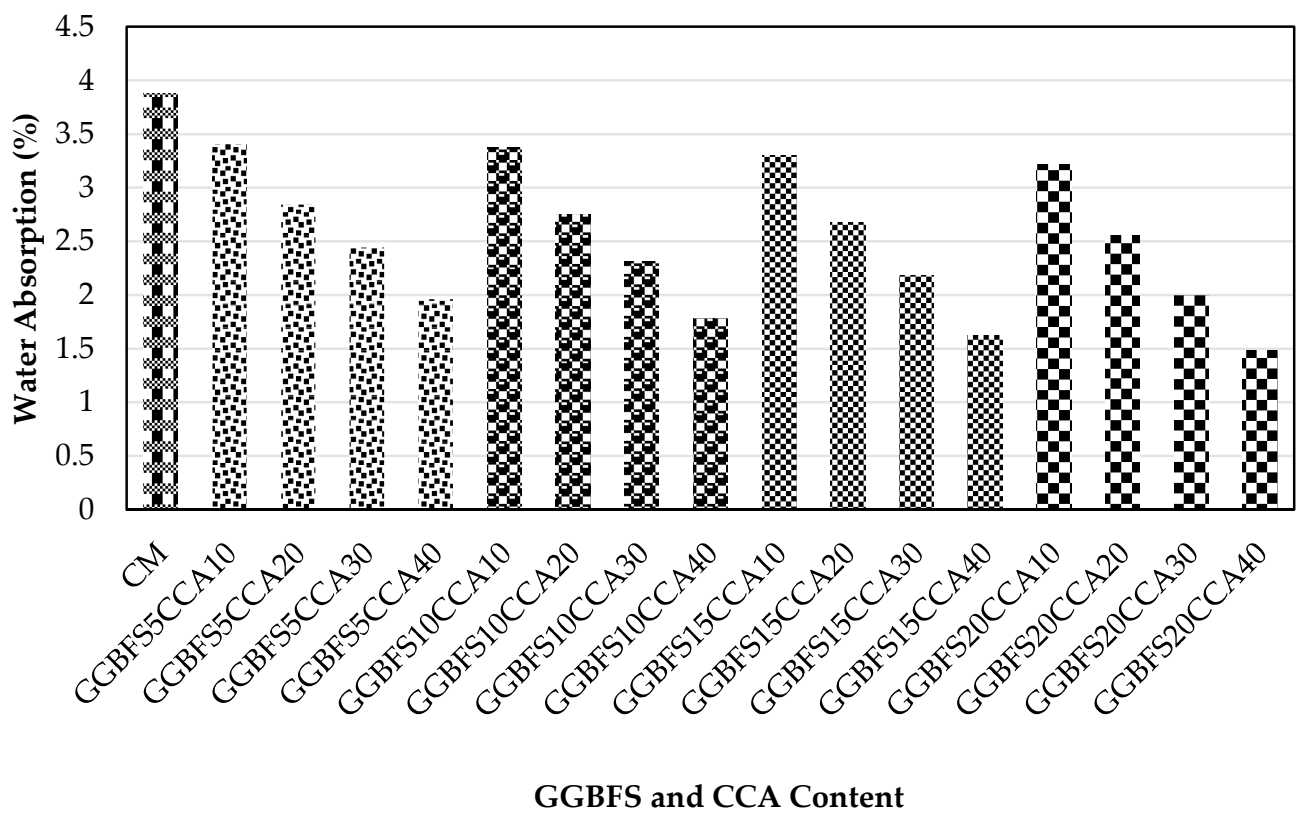

Figure 7. Water absorption of concrete blended with GGBFS along with CCA.

\subsection{Density of Concrete}

We tested the density of concrete on samples made of concrete blended with several dosages of GGBFS to replace PC and CCA to replace fine aggregate, as shown in Figure 8. The concrete density is $2325 \mathrm{~kg} / \mathrm{m}^{3}, 2250 \mathrm{~kg} / \mathrm{m}^{3}, 2200 \mathrm{~kg} / \mathrm{m}^{3}$, and $2140 \mathrm{~kg} / \mathrm{m}^{3}$ with GGBFS levels of $5 \%, 10 \%, 15 \%$, and $20 \%$, respectively, and $2296 \mathrm{~kg} / \mathrm{m}^{3}, 2215 \mathrm{~kg} / \mathrm{m}^{3}$, $2110 \mathrm{~kg} / \mathrm{m}^{3}$, and $2085 \mathrm{~kg} / \mathrm{m}^{3}$ with CCA levels of $5 \%, 10 \%, 15 \%$, and $20 \%$ at 28 days, respectively, lower than that of concrete made of PC only. This shows that the addition of GGBFS as a PC replacement and CCA as a fine aggregate replacement lowers the density of concrete. This experimental work is associated with that of Bheel et al. [51], where the increasing usage of GGBFS and MK as a PC replacement reduced the density of concrete. Similarly, Bheel et al. [53] stated that the density of concrete lowered as the dosages increased of CBA as a replacement for sand. Moreover, we determined the density of concrete specimens blended with GGBFS as a cementitious material along with CCA in place of FA, as demonstrated in Figure 9. The best density is calculated as $2378 \mathrm{~kg} / \mathrm{m}^{3}$ in the concrete mixture made of PC only, and the lowest density is $1935 \mathrm{~kg} / \mathrm{m}^{3}$ 
with GGBFS20CCA40 as a PC and fine aggregate replacement at 28 days. The outcome shows that enhancing the combined use of GGBFS by the weight of PC and replacing FA with CCA in the mixture plummets the density of concrete. The plummeting in the density is associated with the density of the replacement materials GGBFS and CCA. These replacements materials possess lower specific gravity than that of PC and fine aggregate, which results in the reduction in density as well as the reduction in the dead load of concrete. This comparable outcome was explored by Keerio et al. [55], who found that concrete density is reduced as the replacement of PC with SF and FA with glass powder rises. Likewise, Bheel et al. [52] concluded that the use of MHA as a PC replacement along with WSA as a sand replacement results in a decline in the density of concrete.

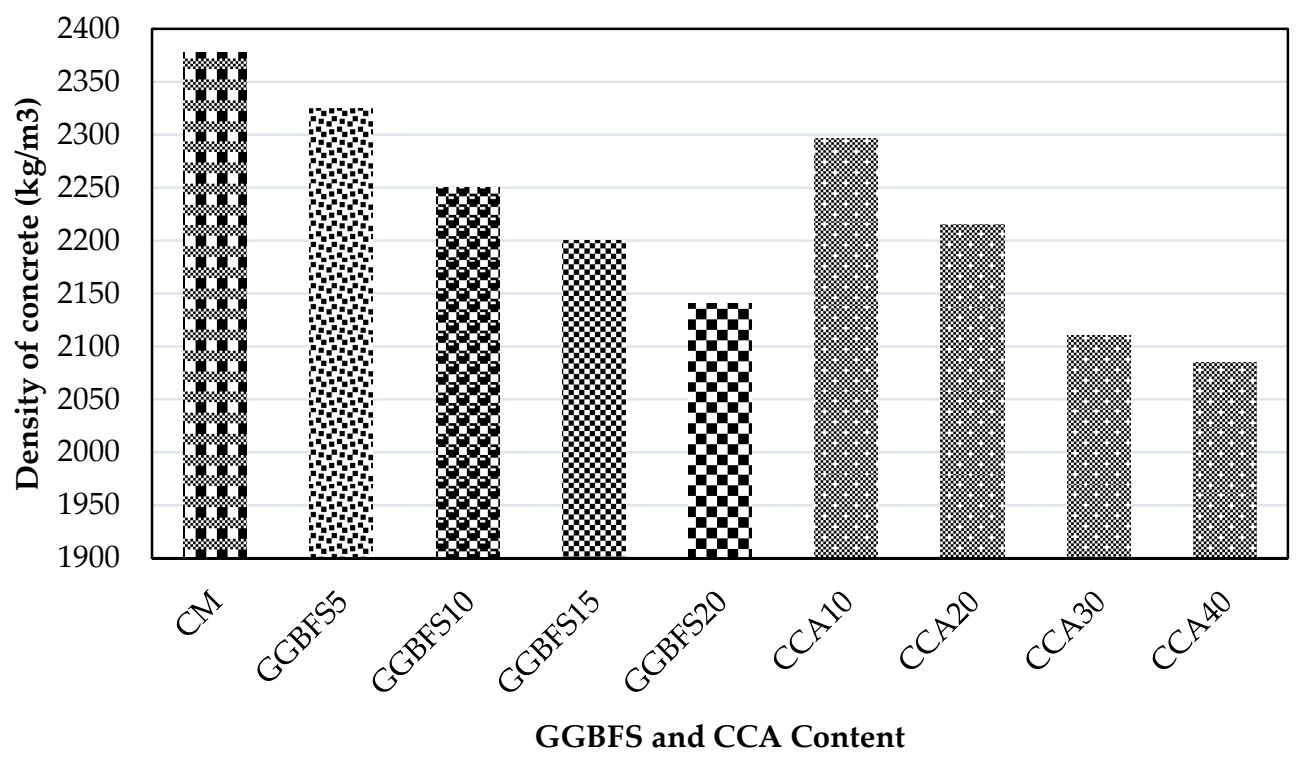

Figure 8. Density of concrete containing GGBFS and CCA.

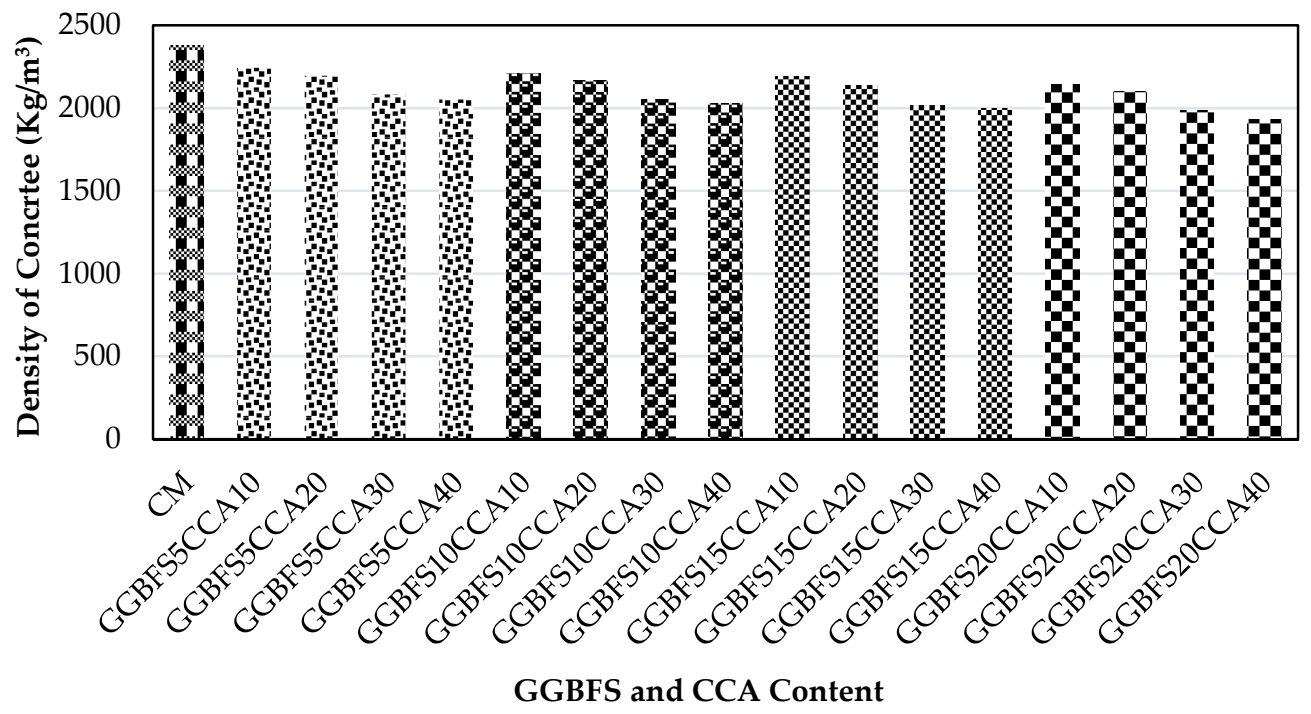

Figure 9. Density of concrete blended with GGBFS along with CCA.

\subsection{Compressive Strength}

Figure 10 displays the concrete mixture blended with GGBFS as a PC replacement and CCA as an FA replacement, analyzing the compressive strength at 28 days. The peak compressive strength is $29.40 \mathrm{MPa}$ with $10 \%$ GGBFS as a PC replacement and $29.58 \mathrm{MP}$ with $30 \%$ CCA as an FA replacement at 28 days. Similarly, the lowest compressive strength is $23.50 \mathrm{MPa}$ with $20 \%$ GGBFS as a PC replacement and $27.18 \mathrm{MPa}$ with $40 \%$ of fine 
aggregate replaced with CCA at 28 days. The compressive strength is heightened with $10 \%$ GGBFS and 30\% CCA. With the further addition of GGBFS and CCA, the compressive strength plummets. The pozzolanic response, in which freely available calcium hydroxide is consumed and secondary calcium silicate hydrate (C-S-H) gel is produced, is responsible for the increased strength when GGBFS content is added. The lower strength gain can be related to the limited supply or availability of $\mathrm{Ca}(\mathrm{OH})_{2}$ used during the pozzolanic reaction; the greater the pozzolan concentration, the more $\mathrm{Ca}(\mathrm{OH})_{2}$ is required. Bheel et al. [51] found that the usage of GGBFS and MK as supplementary cementitious components up to $10 \%$ in concrete could increase the compressive strength at 28 days. Likewise, Bheel et al. [56] informed that the crushing strength was increased by using WSA up to $30 \%$ in concrete at 28 days. Bheel et al. [52] also concluded that the crushing strength was enhanced as the replacement content of sand with wheat straw ash rose to $30 \%$ in the mixture after 28 days.

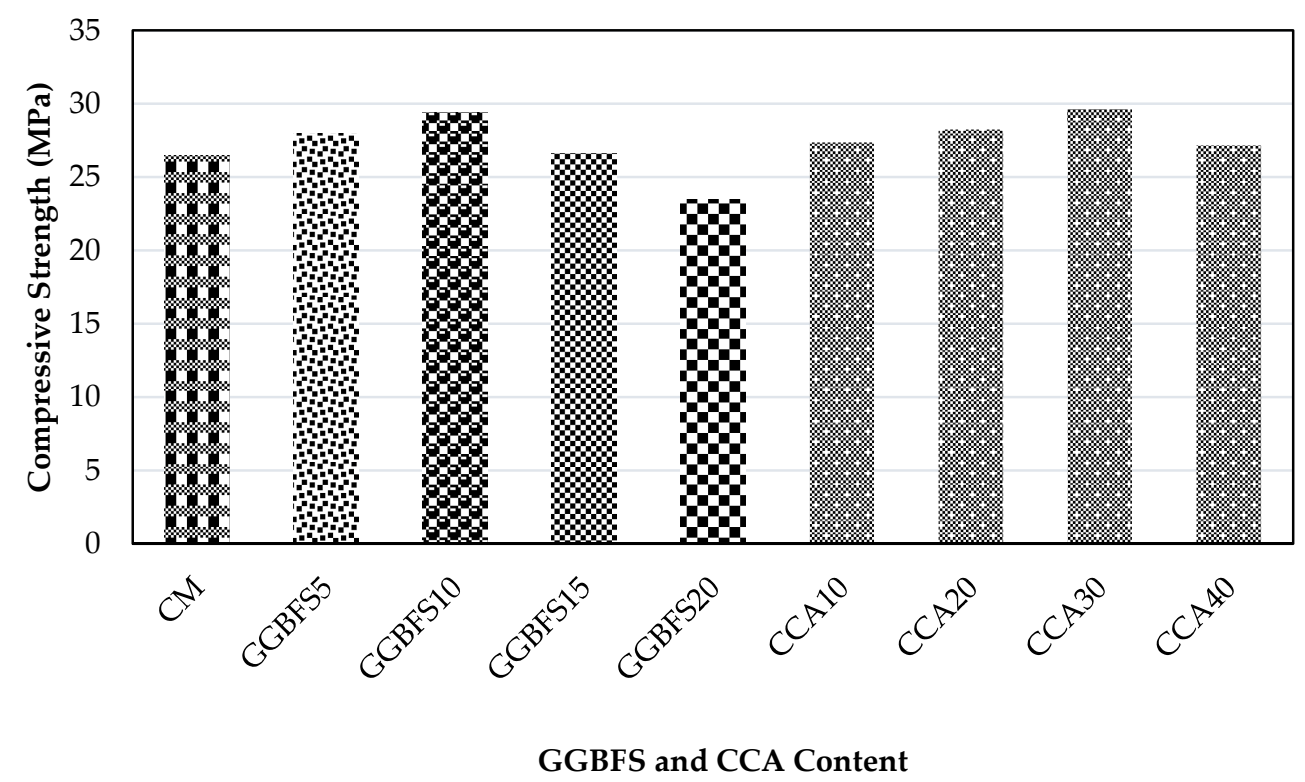

Figure 10. Compressive strength of concrete containing GGBFS and CCA.

Figure 11 depicts the concrete with the accumulation of 5-20\% GGBFS by weight of PC along with $10-40 \%$ of CCA as a sand replacement to analyze the effect of PC and FA replacement on the compressive strength of concrete. The greatest value of compressive strength is $31 \mathrm{MPa}$ with 10\% GGBFS as a PC replacement along with $30 \%$ CCA as an FA replacement, and the lowest value is $21.18 \mathrm{MPa}$ with 20\% GGBFS and $40 \%$ CCA together in the mixture of concrete at 28 days. The compressive strength is heightened at levels of GGBFS up to $10 \%$ CCA up to $30 \%$ in the concrete mixture at 28 days. The enhancement in strength is associated with the high content of silica in GGBFS and CCA, as well as the finer particles of GGBFS and CCA compared to PC, which develops the transition zone of concrete. As more GGBFS and CCA are added to concrete, the dilution effect of GGBFS and CCA might reduce the existing calcium hydroxide for product formation. A comparable trend of investigation was accomplished by Bheel et al. [53], in that the crushing strength was enhanced with the accumulation of $10 \%$ RHA as a PC replacement and 30\% CBA as a sand replacement together in concrete at 28 days. Bheel et al. [52] documented that the crushing strength of the mixture was developed as the quantity of PC was replaced up to $10 \%$ by MHA and FA was replaced up to $30 \%$ by WSA at 28 days. 


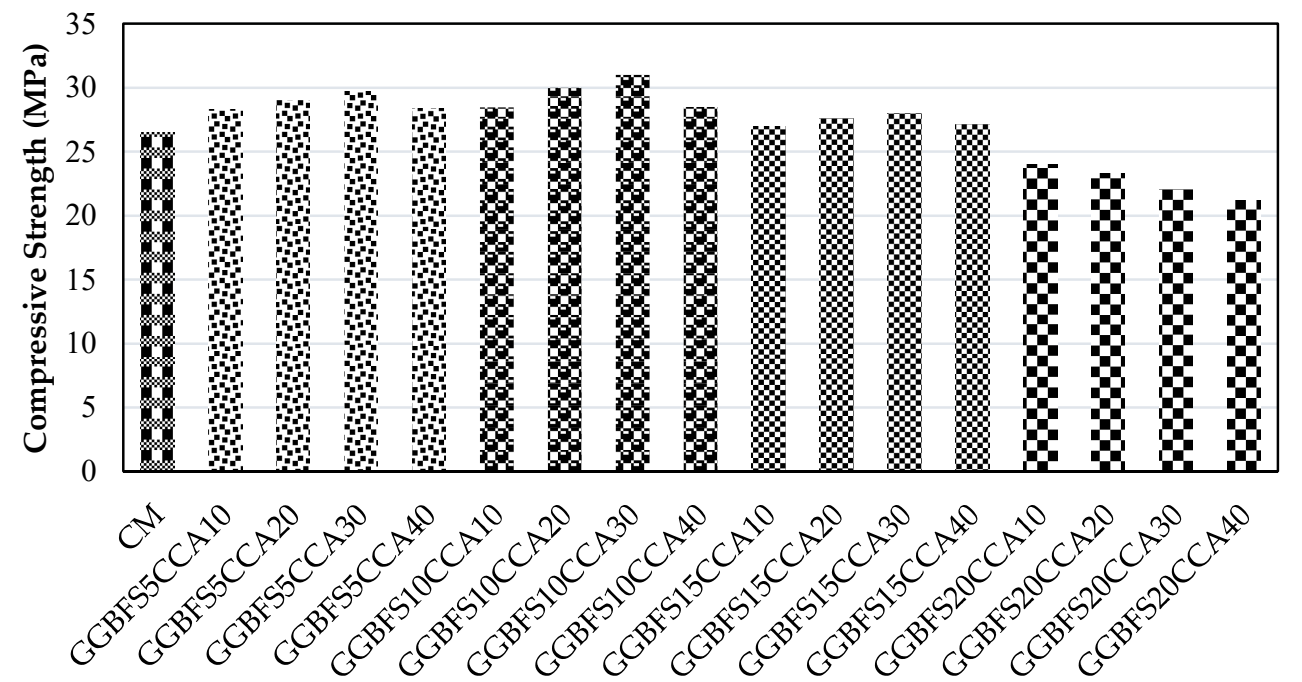

GGBFS and CCA Content

Figure 11. Compressive strength of concrete blended with GGBFS along with CCA.

\subsection{Splitting Tensile Strength}

Figure 12 illustrates the concrete mixtures with 5 to 20\% GGBFS by the weight of PC, exploring the splitting tensile strength of concrete. The optimum strength is achieved at $3.10 \mathrm{MPa}$ with $10 \%$ of GGBFS, and the minimum strength is $2.58 \mathrm{MPa}$ with $20 \%$ of GGBFS at 28 days. The maximum split tensile strength is obtained when using GGBFS as a PC replacement up to $10 \%$; after further accumulation of GGBFS, the strength declines. This aspect is also explored by Bheel et al. [51], who found that the usage of GGBFS and MK up to $10 \%$ by the weight of PC in concrete achieves optimum split tensile strength at 28 days. Similarly, the usage of CCA as a replacement for sand content in concrete is determined by the split tensile strength at 28 days, as indicated in Figure 12 . At $30 \%$ of sand replaced with CCA, the supreme split tensile strength is measured as $3.14 \mathrm{MPa}$ and the smallest strength was measured as $2.86 \mathrm{MPa}$ at $40 \%$ CCA at 28 days. As FA is replaced with CCA up to $30 \%$, the indirect tensile strength increases. The CCA is a well-known pozzolanic material, but it is utilized as a sand replacement in this study. Thus, it has a considerable supply of calcium hydroxide. As a result, the calcium hydroxide is consumed during the pozzolanic reaction caused by CCA, and a secondary C-S-H gel is formed that is responsible for enhancing the tensile strength of concrete. This judgment was provided by Bheel et al. [56], showing that the split tensile strength can be increased when sand is replaced with wheat straw ash up to $30 \%$ and that it begins to decrease after 28 days. Keerio et al. [55] stated that the application of glass powder up to $30 \%$ by the weight of sand in the mixture achieves high split tensile strength after 28 days. Moreover, Figure 13 demonstrates the splitting tensile strength of concrete investigated with the addition of $5-20 \%$ GGBFS by the mass of PC and 10 to $40 \%$ of CCA by the weight of FA together in concrete. The best indirect tensile strength was observed as $3.22 \mathrm{MPa}$ at 10\% GGBFS along with $30 \%$ CCA, and the lowest value was documented as $2.40 \mathrm{MPa}$ at $20 \%$ GGBFS along with $40 \%$ CCA together in concrete at 28 days. The outcome is that the splitting tensile strength is boosted by the accumulation of GGBFS up to $10 \%$ as a replacement for PC and CCA up to $30 \%$ as a replacement for fine aggregate, and after further accumulation of CCA, the strength plummets at 28 days. The increase in split tensile strength is associated with the CCA and GGBFS, which possess more specific surface areas than PC that develop the concrete interfacial transition zone. With further addition of CCA and GGBFS in the mixture, the strength begins to decline, owing to the less pozzolanic response of GGBFS and CCA in the mixture than the PC hydration reaction. Bheel et al. [52] followed a similar research trend in which the split tensile strength was increased by replacing $10 \%$ of PC with MHA $30 \%$ of sand with WSA together in the mixture at 28 days. Keerio et al. [55] found 
that the splitting tensile strength of concrete is enriched with the content of silica fume up to $10 \%$ as a PC replacement and glass powder up to $30 \%$ as an FA replacement after 28 days. In addition, a relationship has been established between the split tensile strength and compressive strength of the concrete containing CCA and GGBFS alone and together at 28 days, shown in Figures 14 and 15, respectively. After 28 days, it split tensile and compressive strength had a strong correlation. When one of these strengths is recognized, the equation shown in Figures 14 and 15 is useful for determining the split tensile strength or compressive strength.

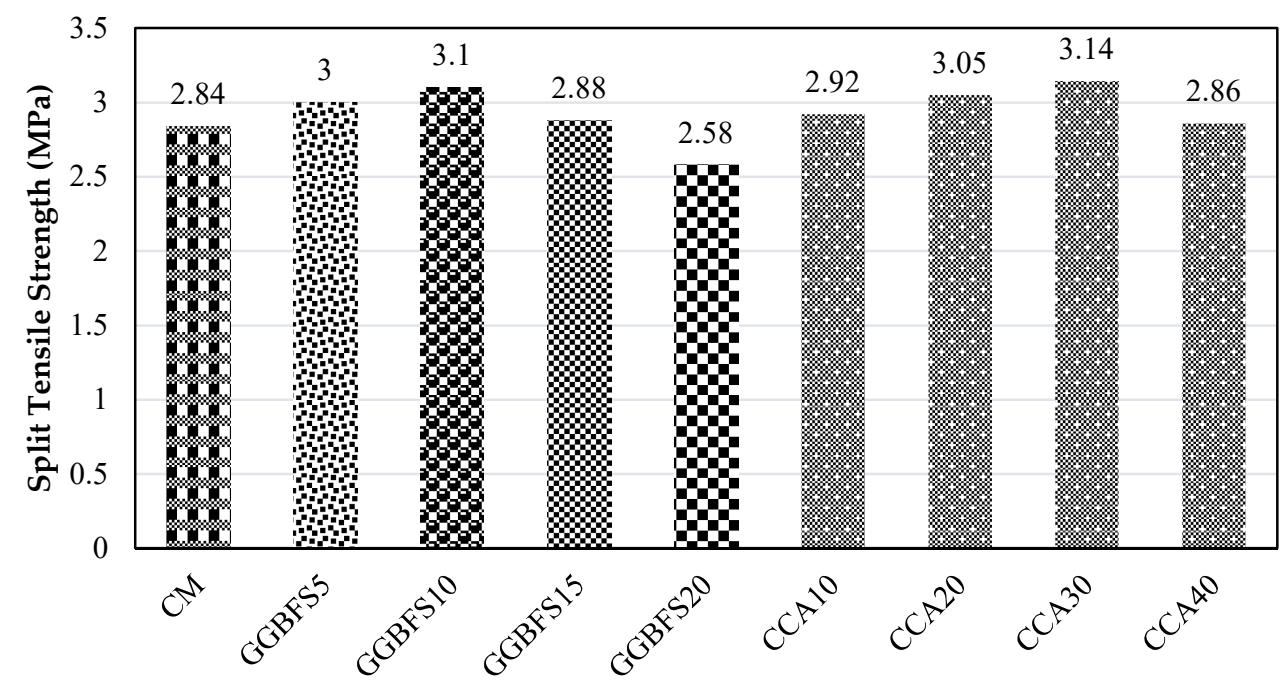

\section{GGBFS and CCA Content}

Figure 12. Splitting tensile strength of concrete containing GGBFS and CCA.

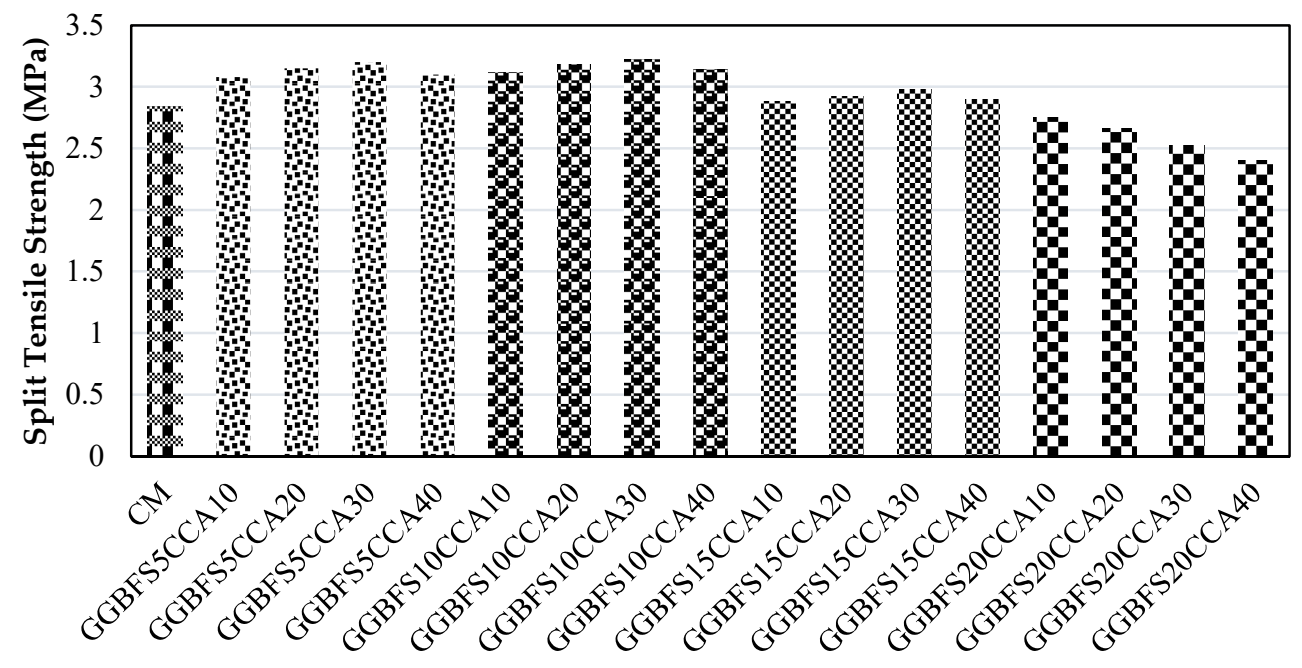

\section{GGBFS and CCA Content}

Figure 13. Splitting tensile strength of concrete blended with GGBFS and CCA. 


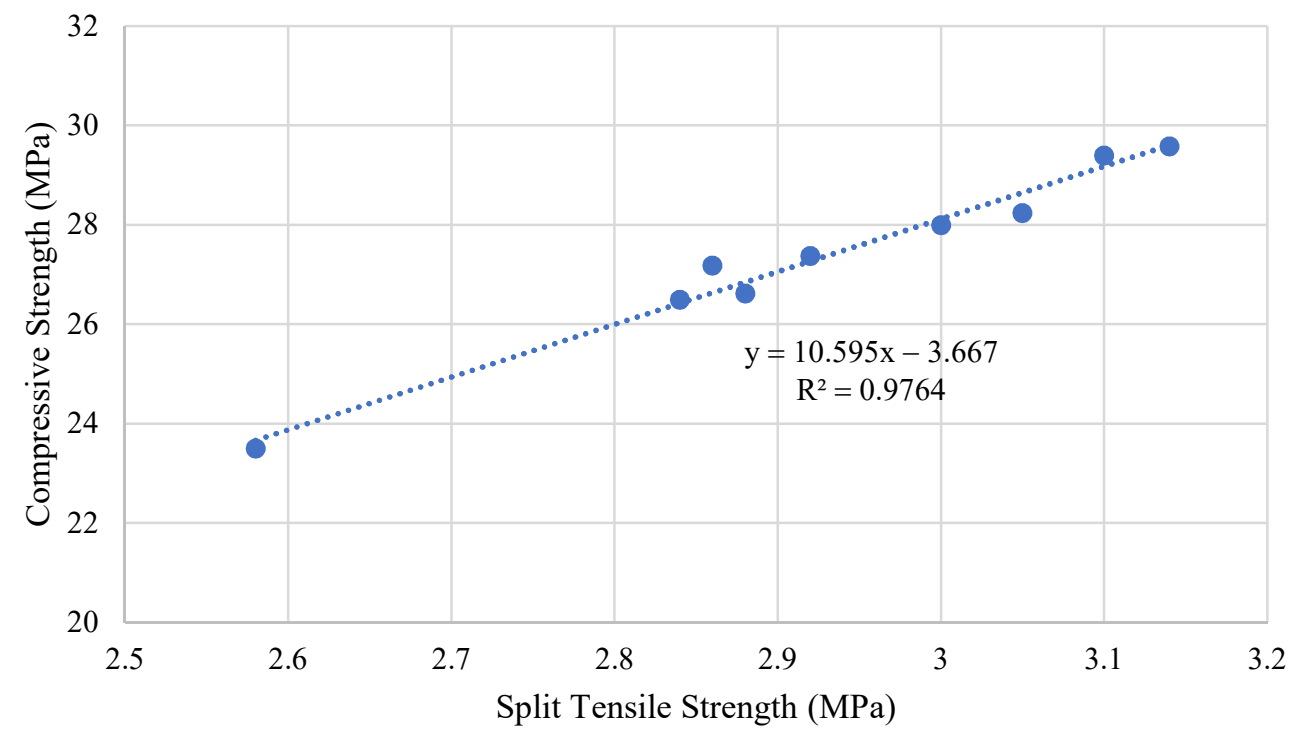

Figure 14. Correlations between the splitting tensile strength and compressive strength of concrete containing CCA and GGBFS alone.

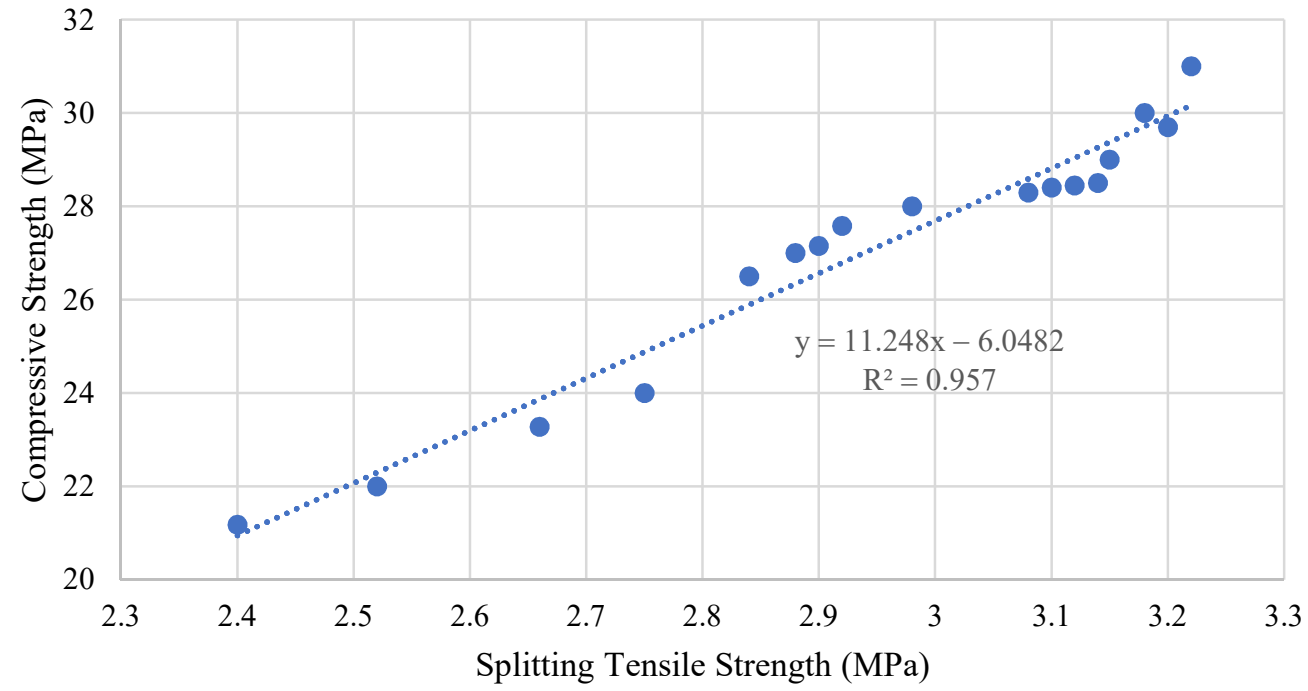

Figure 15. Correlations between the splitting tensile strength and compressive strength of concrete containing CCA and GGBFS together.

\subsection{Sustainability Assessment of Concrete}

We calculated environmental impact assessments for all mixtures blended with various replacements of PC with GGBFS and fine aggregate with CCA both individually and combined to explore the embodied $\mathrm{CO}_{2}$, embodied energy, and eco-strength efficiency of the concrete mixtures. The values of embodied energy and carbon for all concrete constituents were obtained from the literature, as displayed in Table 4 . The embodied carbon and embodied energy values for all concrete mixtures are assessed with Equations (1) and (2), respectively. The symbols of $\mathrm{CO}_{2 e}, E_{e}, i$, and $W_{i}$ in Equation (1) [57] and Equation (2) [57] represent the total embodied carbon, embodied energy, and the weight per unit volume (i.e., $\mathrm{kg} / \mathrm{m}^{3}$ ) for every mixture of concrete, respectively. Moreover, the symbols $\mathrm{CO}_{2 i}$ and $E_{i}$ correspond to the embodied carbon and embodied energy of concrete ingredients, respectively, described in Table 4.

$$
\mathrm{CO}_{2 e}=\sum_{i=1}^{n}\left(\mathrm{~W}_{i} \times \mathrm{CO}_{2 i}\right)
$$




$$
E_{e}=\sum_{i=1}^{n}\left(W_{i} \times E_{i}\right),
$$

Table 4. Embodied carbon and energy of concrete components.

\begin{tabular}{|c|c|c|c|}
\hline Component & $\begin{array}{c}\text { Embodied Carbon } \\
\left(\mathrm{kgCO} / \mathrm{m}^{3}\right)\end{array}$ & $\begin{array}{c}\text { Embodied Energy } \\
(\mathrm{MJ} / \mathrm{kg})\end{array}$ & References \\
\hline Portland Cement & 0.82 & 5.50 & [58] \\
\hline Fine Aggregate & 0.0139 & 0.0048 & [59] \\
\hline Coarse Aggregate & 0.0408 & 0.0048 & [59] \\
\hline GGBFS & 0.07 & 1.33 & {$[60]$} \\
\hline CCA & 0.002 & 0.022 & [40] \\
\hline Water & 0 & 0 & [61] \\
\hline
\end{tabular}

Figure 16 shows the embodied carbon of concrete mixtures blended with various replacements of PC with GGBFS and FA with CCA individually. Figure 16 shows that PC emits the greatest amount of carbon, followed by fine and coarse aggregate. Nonetheless, the impact of GGBFS as a replacement for PC and CCA as a replacement for FA in the mixture of concrete is not visible in the figure; thus, the contribution of these materials to embodied carbon is very small. However, embodied carbon is recorded as 3.95\%, 7.90\%, $11.84 \%$, and $15.76 \%$ while utilizing GGBFS levels of $5 \%, 10 \%, 15 \%$, and $20 \%$, respectively, $0.3 \%, 0.4 \%, 0.6 \%$, and $0.8 \%$ with CCA levels of $10 \%, 20 \%, 30 \%$, and $40 \%$, respectively, less than that of concrete prepared with PC only. It has been detected that the embodied carbon is lowered as the replacement of PC with GGBFS and FA with CCA increases in concrete. Moreover, the optimum embodied carbon is $329.3 \mathrm{kgCO}_{2} / \mathrm{m}^{3}$ with the control mix concrete and the minimum value of embodied carbon is $274.70 \mathrm{kgCO} / \mathrm{m}^{3}$ with GGBFS20CCA40 replacing PC and FA. Figure 17 shows that when the usage of GGBFS as a PC replacement along with CCA as an FA replacement increases in concrete, the embodied carbon decreases.

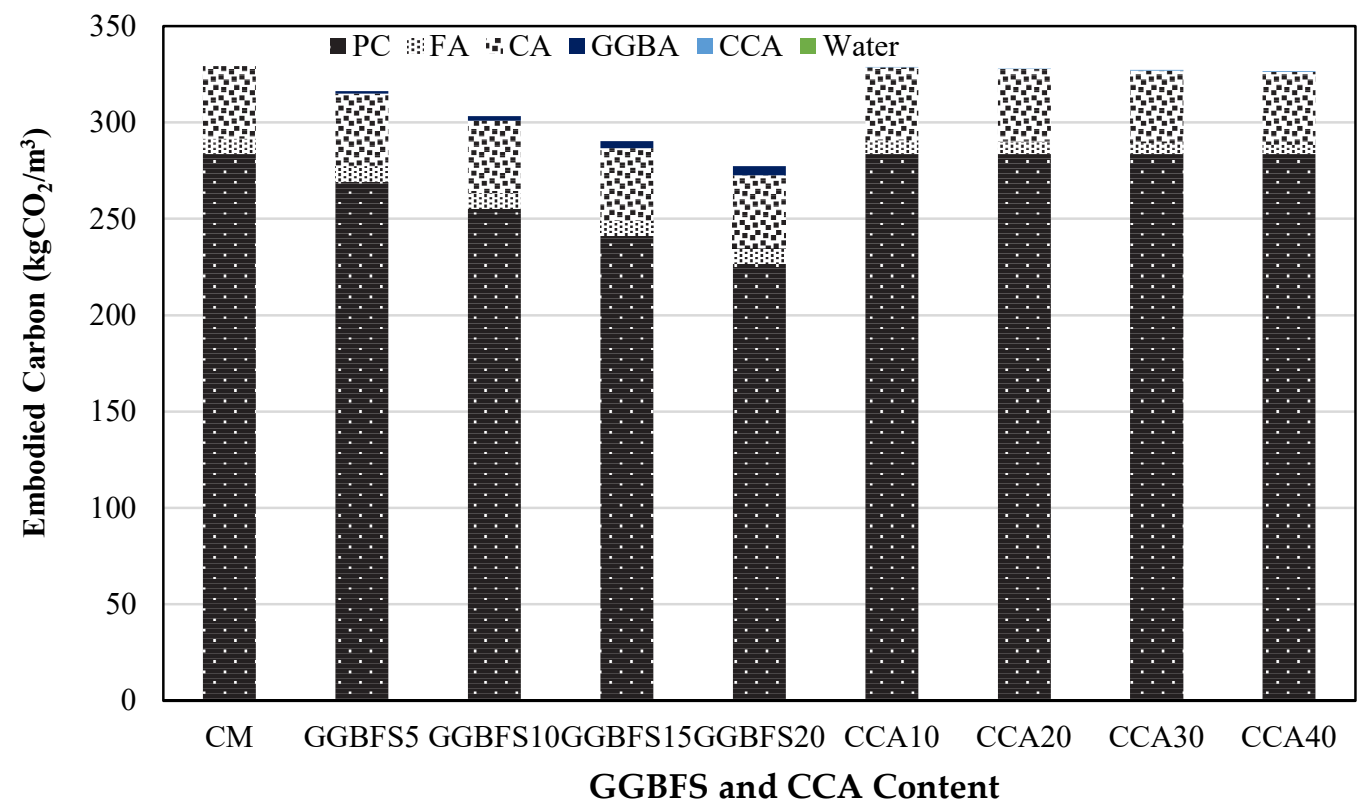

Figure 16. Embodied carbon of concrete containing GGBFS and CCA. 


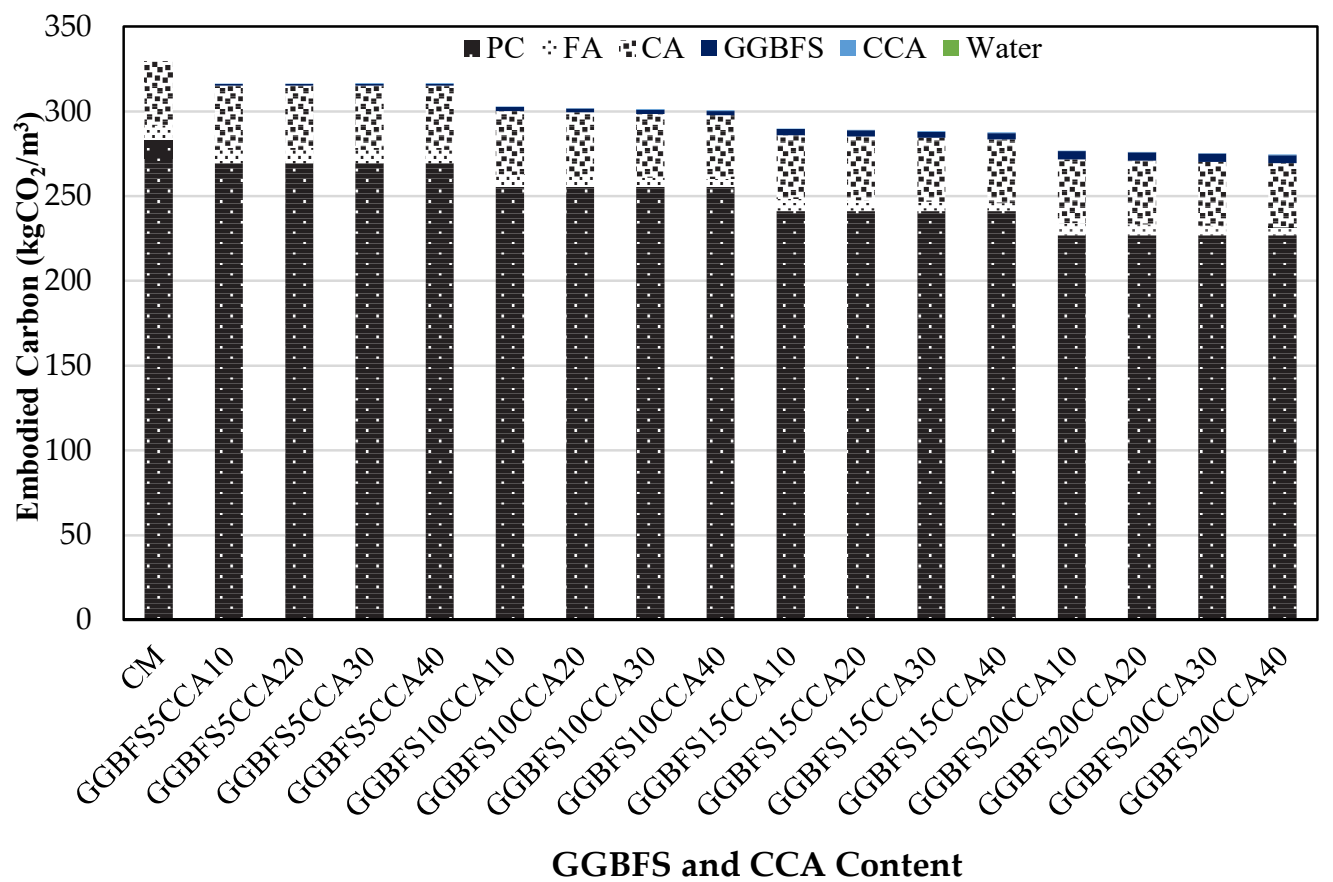

Figure 17. Embodied carbon of concrete blended with GGBFS along with CCA.

Figures 18 and 19 show the embodied energy of concrete as determined by various percentages of GGBFS as a cementitious material and CCA as a replacement for FA, both individually and combined. The amount of embodied carbon is $3.78 \%, 7.56 \%, 11.34 \%$, and $15.12 \%$ with GGBFS levels of $5 \%, 10 \%, 15 \%$, and $20 \%$, respectively, lower compared to concrete made of PC only, and $0.05 \%, 0.1 \%, 0.15 \%$, and $0.2 \%$ with CCA levels of $10 \%, 20 \%$, $30 \%$, and $40 \%$, respectively, slightly higher compared to concrete made of PC only. It is seen in Figure 18 that the highest quantity of embodied energy is produced by PC only as compared to other components of concrete. The other components of concrete are not visible in Figures 18 and 19. Nevertheless, it can be recognized that the embodied energy has plummeted as the replacement of PC with GGBFS and FA with CCA grows in concrete. This improvement in the sustainability of concrete is achieved blended with GGBFS by the weight of PC and CCA as a fine aggregate replacement both individually and combined in concrete. The performance and sustainability of concrete can be developed by applying such waste resources.

Furthermore, the eco-strength efficiency of concrete is calculated based on the compressive strength by using Equation (3) [62]:

$$
\text { Eco }- \text { strength efficiency }=\frac{\text { Average } 28-\text { Days Compressive Strength of Concrete }}{\text { Total Embodied Carbon of Concrete }}
$$

Figure 20 illustrates the eco-strength efficiency of concrete calculated with the addition of GGBFS as a cementitious material and FA replaced with CCA individually and combined in a mixture. The best eco-strength efficiency is $0.097 \mathrm{MPa} / \mathrm{kgCO}_{2} \cdot \mathrm{m}^{3}$ with $10 \%$ GGBFS as a PC replacement, $0.090 \mathrm{MPa} / \mathrm{kgCO}_{2} \cdot \mathrm{m}^{3}$ with $30 \%$ CCA as an FA replacement, and $0.10 \mathrm{MPa} / \mathrm{kgCO}_{2} \cdot \mathrm{m}^{3}$ with GGBFS10CCA30 replacing both PC and FA. In the same way, the minimum value is determined as $0.085 \mathrm{MPa} / \mathrm{kgCO}_{2} \cdot \mathrm{m}^{3}$ with $20 \%$ GGBFS, $0.083 \mathrm{MPa} / \mathrm{kgCO}_{2} \cdot \mathrm{m}^{3}$ with $40 \% \mathrm{CCA}$, and $0.077 \mathrm{MPa} / \mathrm{kgCO}_{2} \cdot \mathrm{m}^{3}$ with GGBFS20CCA40. The outcome is that the eco-strength efficiency is enhanced while replacing up to $10 \%$ of PC with GGBFS and replacing up to $30 \%$ of FA with CCA. This improvement in eco-strength efficiency is due to the lowest embodied carbon and maximum compressive strength among the mixtures, and with further addition of these materials in concrete, these are reduced. This decrease in eco-strength efficiency is due to the higher accumulation of GGBFS, which resulted in more $\mathrm{CO}_{2}$ emissions and were not offset by the reduction in $\mathrm{CO}_{2}$ emissions 
achieved by the accumulation of CCA. Furthermore, replacing FA with CCA resulted in a reduction in compressive strength. Moreover, the combined usage of GGBFS along with CCA as a fine aggregate up to GGBFS10CCA30 in concrete obtained the maximum eco-strength of concrete, as shown in Figure 21. This is due to the lowest embodied carbon and maximum compressive strength among the various mixtures. Higher eco-strength efficiency was seen when GGBFS and CCA were used together, ascribed to their strength gaining. Previous research $[63,64]$ demonstrated that eco-strength efficiency varied due to the utilization of these materials, but that overall, eco-strength efficiency improved as the PC substitution level rose. The eco-strength efficiency estimates reported in this investigation for combined use are consistent with prior findings [62] using two SCMs.

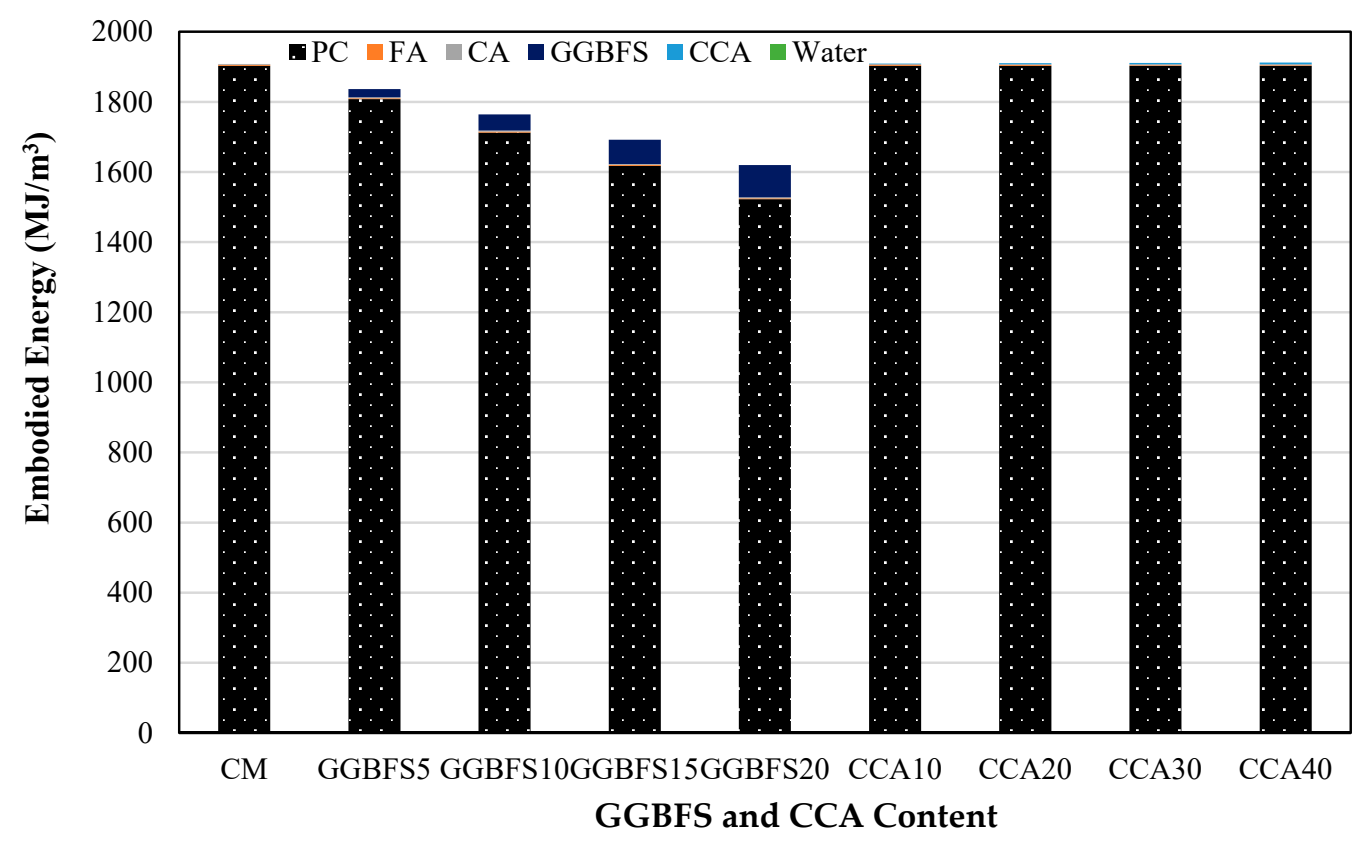

Figure 18. Embodied energy of concrete containing GGBFS and CCA.

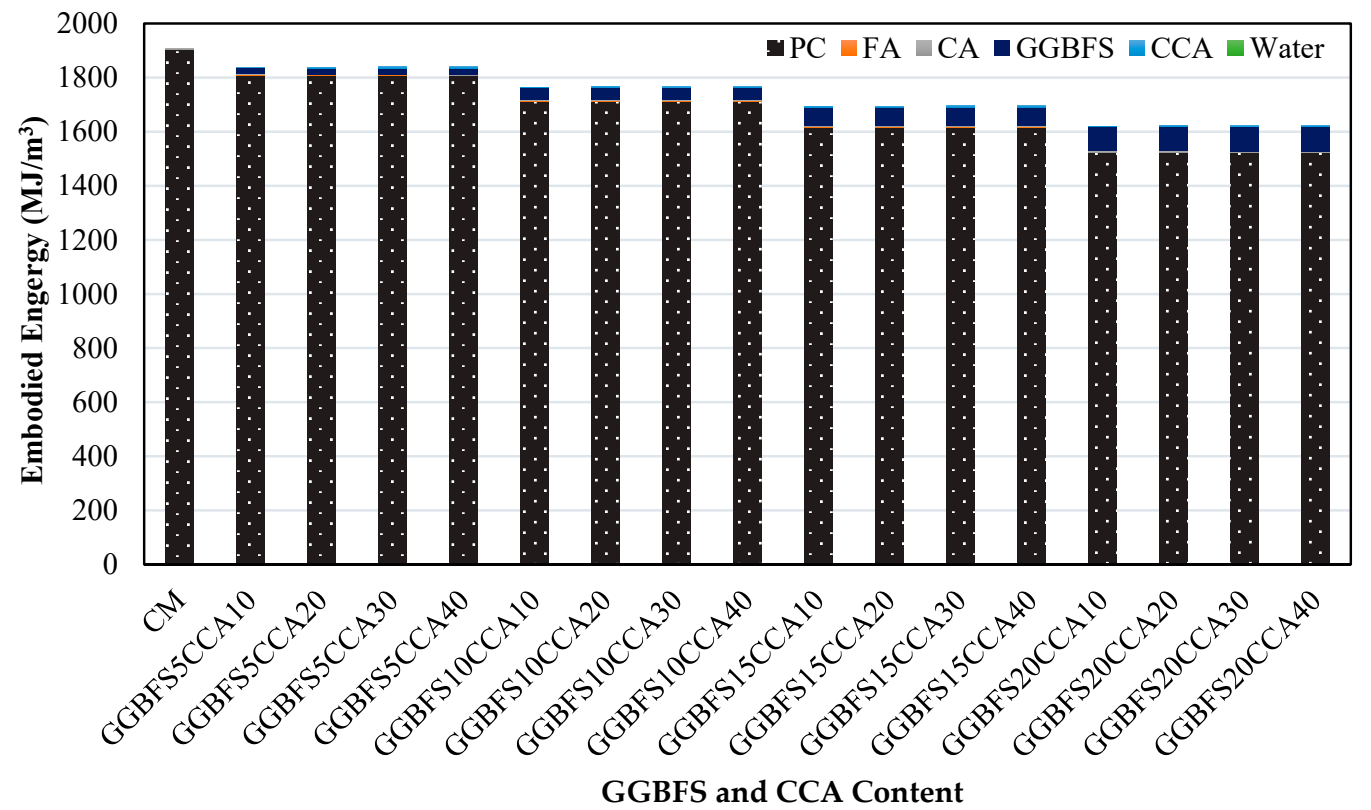

Figure 19. Embodied energy of concrete blended with GGBFS along with CCA. 


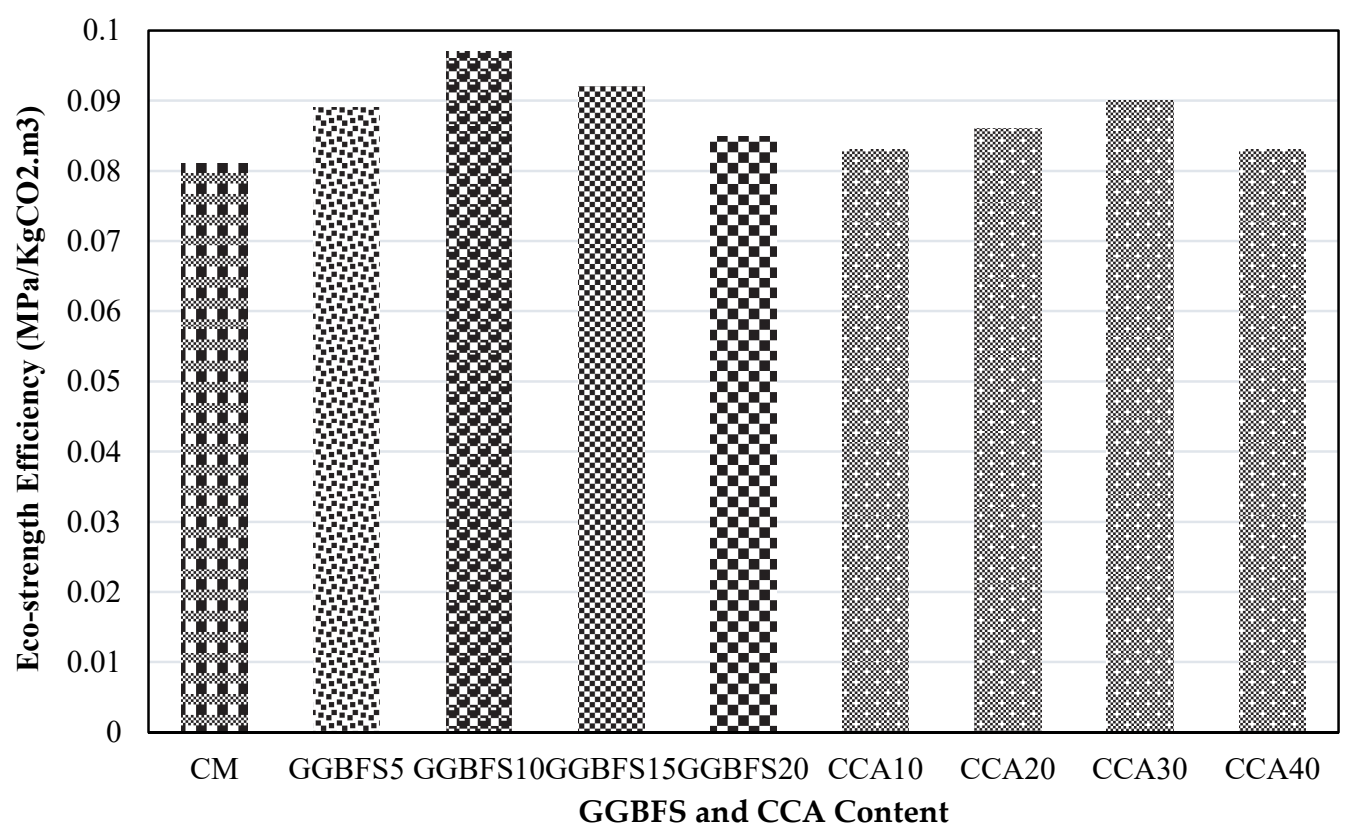

Figure 20. Eco-strength efficiency of concrete containing GGBFS and CCA.

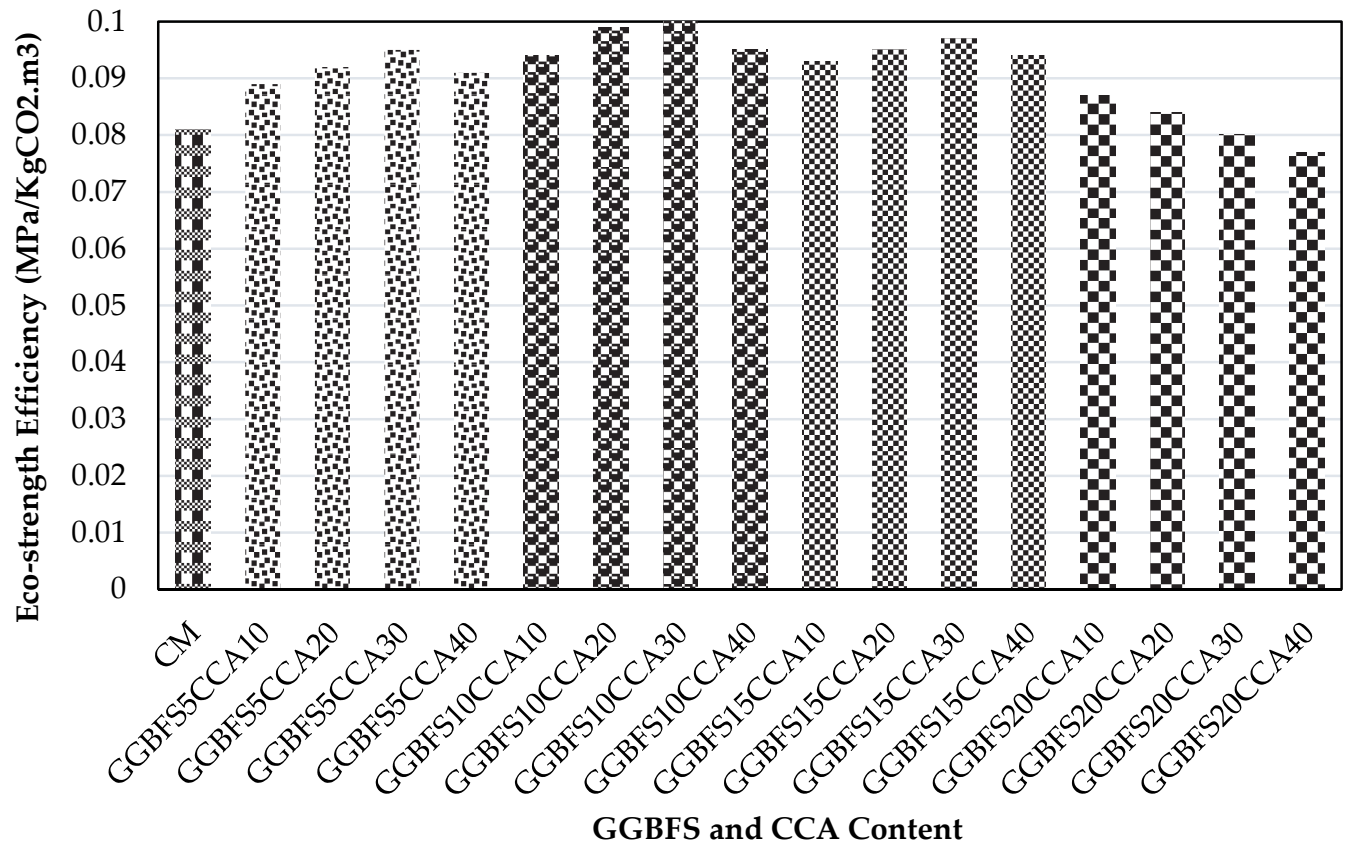

Figure 21. Eco-strength efficiency of the mixture containing GGBFS along with CCA.

\section{Conclusions}

This study investigated the utilization of CCA as a fine aggregate and GGBFS as a cementitious material in concrete production. The primary goal of this investigation was to assess the influence of these replacement materials on the workability and physical, mechanical, and embodied carbon characteristics of the concrete mixtures. The following findings can be taken from this investigation:

- The slump is obtained at $49 \mathrm{~mm}, 41 \mathrm{~mm}, 36 \mathrm{~mm}$, and $27 \mathrm{~mm}$ at 5\%,10\%, 15\%, and $20 \%$ of GGBFS as a cementitious material, respectively, and at $46 \mathrm{~mm}, 38 \mathrm{~mm}, 31 \mathrm{~mm}$, and $22 \mathrm{~mm}$ at $10 \%, 20 \%, 30 \%$, and $40 \%$ of CCA as an FA, respectively, lower than that of concrete made of PC only. Similarly, the optimum workability is recorded at $56 \mathrm{~mm}$ in the control mixture concrete, and the smallest amount of workability is noted as $21.18 \mathrm{~mm}$ in GGBFS20CCA40. It can be concluded that the workability dropped with 
the addition of GGBFS as a replacement for PC and CCA as a fine aggregate, both separate and together in the mixture.

- The optimum water absorption was $3.88 \%$ in the control mix while the minimum water absorption was $2.38 \%$ with $20 \%$ GGBFS as a PC replacement and $2.15 \%$ with $40 \% \mathrm{FA}$ as a CCA replacement, followed by $1.48 \%$ with GGBFS20CCA40 at 28 days. The water absorption dropped as the amounts of GGBFS and CCA, both separate and together, rise.

- The control mixture of concrete provides the best density, $2378 \mathrm{~kg} / \mathrm{m}^{3}$, while lower density of $2140 \mathrm{~kg} / \mathrm{m}^{3}$ was found with $20 \%$ of PC replaced with GGBFS, followed by $2085 \mathrm{~kg} / \mathrm{m}^{3}$ with $40 \%$ of fine aggregate replaced with CCA and $1935 \mathrm{~kg} / \mathrm{m}^{3}$ with GGBFS20CCA40 at 28 days. The result is that the density plummeted with increasing replacement content of PC with GGBFS and FA with CCA, both separately and together.

- The concrete mixtures with $10 \%$ of PC replaced with GGBFS, $30 \%$ of fine aggregate replaced with CCA, and GGBFS10CCA30 provide the highest compressive strength values, estimated as $29 \mathrm{MPa}, 29.58 \mathrm{MPa}$, and $31 \mathrm{MPa}$, respectively, while the lowest compressive strength values are 23.50 MPa with 20\% GGBFS, 27.18 MPa with $40 \%$ CCA, and $21.18 \mathrm{MPa}$ with GGBFS20CCA40 at 28 days. The result is that the crushing strength is boosted with GGBFS up to $10 \%$ and CCA up to $30 \%$ in concrete.

- The top indirect tensile strengths were 3.10 MPa using 10\% GGBFS, 3.14 MPa using $30 \%$ CCA, and 3.22 MPa using GGBFS10CCA30, while the minimum tensile strengths were $2.58 \mathrm{MPa}$ with $20 \%$, GGBFS 2.86 MPa with $40 \%$ CCA, and $2.40 \mathrm{MPa}$ with GGBFS20CCA40 at 28 days. The result is that the split tensile strength of concrete is enhanced while increasing GGBFS up to $10 \%$ CCA up to $30 \%$.

- The embodied carbon and energy levels in concrete are reduced as the proportions of GGBFS by the weight of PC rise. Similarly, the embodied carbon of concrete is reduced while replacing the FA with CCA in concrete, but the embodied energy of concrete is improved with CCA as fine aggregate. Moreover, the embodied carbon and energy are decreased, whereas the content of GGBFS by the weight of PC along with FA replaced with CCA increases in the concrete mixture.

- Based on the experimental findings, using GGBFS up to $10 \%$ as a replacement for PC and CCA up to $30 \%$ as a sand replacement separately and together in concrete delivers the best results for structural applications.

Author Contributions: N.B.: experimental work, data analysis, writing draft, review and editing; M.O.A.A.: supervision, conception, reviewing, and validation; Y.L.: supervision, editing, reviewing, funding acquisition; T.T.: writing, editing, proofreading; P.A.: writing, editing, reviewing; N.H.S.: reviewing, editing, proofreading; L.M.B.R.: editing, proofreading. All authors have read and agreed to the published version of the manuscript.

Funding: The authors are thankful for the financial support from the National Natural Science Foundation of China (NSFC 51908012), the Postdoctoral Research Foundation of China (2019M660962), and the International Research Cooperation Seed Fund of Beijing University of Technology (2021B11).

Institutional Review Board Statement: Not applicable.

Informed Consent Statement: Not applicable.

Data Availability Statement: Not applicable.

Acknowledgments: The authors are grateful to the HCST, Hyderabad, Sindh, Pakistan, which provided the necessary instruments to perform this experimental work.

Conflicts of Interest: The authors declare no conflict of interest.

\section{References}

1. Manimaran, A.; Somasundaram, M.; Ravichandran, P.T. Experimental study on partial replacement of coarse aggregate by bamboo and fine aggregate by quarry dust in concrete. Int. J. Civ. Eng. Technol. 2017, 8, 1019-1027. 
2. Ghorbani, S.; Taji, I.; De Brito, J.; Negahban, M.; Ghorbani, S.; Tavakkolizadeh, M.; Davoodi, A. Mechanical and durability behaviour of concrete with granite waste dust as partial cement replacement under adverse exposure conditions. Constr. Build. Mater. 2019, 194, 143-152. [CrossRef]

3. Shirule, P.A.; Rahman, A.; Gupta, R.D. Partial replacement of cement with marble dust powder. Int. J. Adv. Eng. Res. Stud. 2012, $1,2249$.

4. Farzampour, A. Temperature and humidity effects on behavior of grouts. Adv. Concr. Constr. 2017, 5, 659-669.

5. Farzampour, A. Compressive behavior of concrete under environmental effects. In Compressive Strength of Concrete; IntechOpen: London, UK, 2019.

6. Alex, J.; Dhanalakshmi, J.; Ambedkar, B. Experimental investigation on rice husk ash as cement replacement on concrete production. Constr. Build. Mater. 2016, 127, 353-362. [CrossRef]

7. Aprianti, E.; Shafigh, P.; Bahri, S.; Farahani, J.N. Supplementary cementitious materials origin from agricultural wastes-A review. Constr. Build. Mater. 2015, 74, 176-187. [CrossRef]

8. Hrabová, K.; Lehner, P.; Ghosh, P.; Konečný, P.; Teplý, B. Sustainability levels in comparison with mechanical properties and durability of pumice high-performance concrete. Appl. Sci. 2021, 11, 4964. [CrossRef]

9. Afroughsabet, V.; Biolzi, L.; Monteiro, P.J.M.; Gastaldi, M.M. Investigation of the mechanical and durability properties of sustainable high performance concrete based on calcium sulfoaluminate cement. J. Build. Eng. 2021, 43, 1-14. [CrossRef]

10. Awoyera, P.O.; Adesina, A.; Gobinath, R. Role of recycling fine materials as filler for improving performance of concrete-a review. Aust. J. Civ. Eng. 2019, 17, 85-95. [CrossRef]

11. Burroughs, J.F.; Weiss, C.A., Jr.; Shannon, J.D.; Haddock, J.E.; Weiss, J. Modeling the Influence of Changes in Silica Fume on Concrete Performance. J. Mater. Civ. Eng. 2021, 33, 04020500. [CrossRef]

12. Bheel, N.; Mahro, S.K.; Adesina, A. Influence of coconut shell ash on workability, mechanical properties, and embodied carbon of concrete. Environ. Sci. Pollut. Res. 2021, 28, 5682-5692. [CrossRef]

13. Zahmak, A.; Abdallah, M.; Jarah, B.; Arab, M.G. Environmental performance of alkali-activated binders for ground improvement. Transp. Geotech. 2021, 31, 100631. [CrossRef]

14. Shakouri, M.; Exstrom, C.L.; Ramanathan, S.; Suraneni, P. Hydration, strength, and durability of cementitious materials incorporating untreated corn cob ash. Constr. Build. Mater. 2020, 243, 118171. [CrossRef]

15. Keerio, M.A.; Saand, A.; Chaudhry, R.; Bheel, N.; Soohu, S. The Effect of Local Metakaolin Developed from Natural Material Soorh on Selected Properties of Concrete/Mortar. In Silicon; Springer: Berlin/Heidelberg, Germany, 2021; pp. 1-10.

16. Dayo, A.A.; Kumar, A.; Raja, A.; Bheel, N.; Shaikh, Z.H. Use of sugarcane bagasse ash as a fine aggregate in cement concrete. Eng. Sci. Technol. Int. Res. J. 2019, 3, 8-11.

17. De Maeijer, P.K.; Craeye, B.; Snellings, R.; Kazemi-Kamyab, H.; Loots, M.; Janssens, K.; Nuyts, G. Effect of ultra-fine fly ash on concrete performance and durability. Constr. Build. Mater. 2020, 263, 120493. [CrossRef]

18. Ikponmwosa, E.E.; Ehikhuenmen, S.; Emeshie, J.; Adesina, A. Performance of coconut shell alkali-activated concrete: Experimental investigation and statistical modelling. Silicon 2021, 13, 335-340. [CrossRef]

19. Öz, H.Ö.; Gesoglu, M.; Güneyisi, E.; Sor, N.H. Self-Consolidating Concretes Made with Cold-Bonded Fly Ash Lightweight Aggregates. ACI Mater. J. 2017, 114. [CrossRef]

20. Elchalakani, M.; Aly, T.; Abu-Aisheh, E. Sustainable concrete with high volume GGBFS to build Masdar City in the UAE. Case Stud. Constr. Mater. 2014, 1, 10-24. [CrossRef]

21. Sor, N.A.H. The effect of superplasticizer dosage on fresh properties of self-compacting lightweight concrete produced with coarse pumice aggregate. J. Garmian Univ. 2018, 5, 190-209.

22. Wang, H.Y. The effects of elevated temperature on cement paste containing GGBFS. Cem. Concr. Compos. 2008, 30, 992-999. [CrossRef]

23. Kuo, W.T.; Wang, H.Y.; Shu, C.Y. Engineering properties of cementless concrete produced from GGBFS and recycled desulfurization slag. Constr. Build. Mater. 2014, 63, 189-196. [CrossRef]

24. Shariq, M.; Prasad, J.; Masood, A. Effect of GGBFS on time dependent compressive strength of concrete. Constr. Build. Mater. 2010, 24, 1469-1478. [CrossRef]

25. Shoubi, M.V.; Barough, A.S.; Amirsoleimani, O. Assessment of the roles of various cement replacements in achieving the sustainable and high-performance concrete. Int. J. Adv. Eng. Technol. 2013, 6, 68.

26. Suresh, D.; Nagaraju, K. Ground granulated blast slag (GGBS) in concrete-a review. IOSR J. Mech. Civ. Eng. 2015, $12,76-82$.

27. Siddique, R.; Kaur, D. Properties of concrete containing ground granulated blast furnace slag (GGBFS) at elevated temperatures. J. Adv. Res. 2012, 3, 45-51. [CrossRef]

28. Cervantes, V.; Roesler, J. Ground Granulated Blast Furnace Slag; Technical Note; Center of Excellence for Airport Technology: Champaign, IL, USA, 2007; pp. 1-4.

29. Karri, S.K.; Rao, G.R.; Raju, P.M. Strength and durability studies on GGBS concrete. SSRG Int. J. Civ. Eng. (SSRG-IJCE) 2015, 2, 34-41. [CrossRef]

30. Malagavelli, V.; Rao, P.N. High performance concrete with GGBS and ROBO sand. Int. J. Eng. Sci. Technol. 2010, 2, 5107-5113.

31. Cahyani, R.A.T.; Rusdianto, Y. Concrete Performance with Ground Granulated Blast Furnace Slag as Supplementary Cementitious Materials. In IOP Conference Series: Materials Science and Engineering. IOP Publ. 2020, 771, 012062. 
32. Rughooputh, R.; Rana, J. Partial replacement of cement by ground granulated blast furnace slag in concrete. J. Emerg. Trends Eng. Appl. Sci. 2014, 5, 340-343.

33. Raman, J.V.M.; Krishnan, V.M. Partial Replacement of Cement with GGBS in Self Compacting Concrete for Sustainable Construction. SSRG Int. J. Civ. Eng. 2017, 4, 22-25.

34. Arivalagan, S. Sustainable studies on concrete with GGBS as a replacement material in cement. Jordan J. Civ. Eng. 2014, 8, 263-270.

35. Anand, V.; Kumar, A.P. Durability studies on high volume ground granulated blast furnace slag concrete. Int. J. Civ. Eng. Technol. (IJCIET) 2013, 9, 1247-1255.

36. Yang, H.-M.; Kwon, S.-J.; Myung, N.V.; Singh, J.K.; Lee, H.-S.; Mandal, S. Evaluation of strength development in concrete with ground granulated blast furnace slag using apparent activation energy. Materials 2020, 13, 442. [CrossRef]

37. Leung, P.W.; Wong, H.D. Final Report on Durability and Strength Development of Ground Granulated Blast Furnace Slag Concrete; Geotechnical Engineering Office, Civil Engineering and Development Department, The Government of Hong Kong: Hong Kong, China, 2010.

38. Hilal, N.; Sor, N.H.; Faraj, R.H. Development of eco-efficient lightweight self-compacting concrete with high volume of recycled EPS waste materials. Environ. Sci. Pollut. Res. 2021, 28, 50028-50051. [CrossRef] [PubMed]

39. USDA-National Agricultural Statistics Service-Charts and Maps—Corn: Production by Year, US (n.d.). Available online: https:/ / www.nass.usda.gov/Charts_and_Maps/Field_Crops/cornprod.php (accessed on 19 March 2020).

40. Bheel, N.; Adesina, A. Influence of binary blend of corn cob ash and glass powder as partial replacement of cement in concrete. Silicon 2021, 13, 1647-1654. [CrossRef]

41. Akhter, M. Experimental Study on Effect of Wood Ash on Strength of Concrete. Int. Res. J. Eng. Technol. 2017, 4, 1252-1254.

42. Desai, P.H. Experimental study on corn cob ash powder as partial replacement of cement in concrete. Int. Res. J. Eng. Technol. (IRJET) 2018, 5, 724-728.

43. Adesanya, D.A.; Raheem, A.A. A study of the workability and compressive strength characteristics of corn cob ash blended cement concrete. Constr. Build. Mater. 2009, 23, 311-317. [CrossRef]

44. Adesanya, D.A.; Raheem, A.A. A study of the permeability and acid attack of corn cob ash blended cements. Constr. Build. Mater. 2010, 24, 403-409. [CrossRef]

45. Owolabi, T.A.; Oladipo, I.O.; Popoola, O.O. Effect of Corncob Ash as Partial Substitute For Cement In Concrete. N. Y. Sci. J. 2015, $8,1-4$.

46. $\quad$ BS EN 12350-2. Testing Fresh Concrete; Part 2: Slump-Test; BSI: Cambridge, UK, 2009.

47. BS 1881 Part 122. Method, for Determination of Water Absorption; British Standards Institution: London, UK, 1983.

48. BS EN 12390-7:2000 Part 7. Density of Hardened Concrete; British Standards Institution: Cambridge, UK, $2000 ;$ p. 389.

49. BS EN 12390-3. Testing harden concrete. In Compressive Strength of Test Specimens; BSI: Cambridge, UK, 2009.

50. BS EN 12390-6. Testing hardened concrete. In Tensile Splitting Strength of Test Specimens; BSI: Cambridge, UK, 2009.

51. Bheel, N.; Abbasi, S.A.; Awoyera, P.; Olalusi, O.B.; Sohu, S.; Rondon, C.; Echeverría, A.M. Fresh and hardened properties of concrete incorporating binary blend of metakaolin and ground granulated blast furnace slag as supplementary cementitious material. Adv. Civ. Eng. 2020, 2020, 8851030. [CrossRef]

52. Bheel, N.; Ali, M.O.A.; KIRGIZ, M.S.; de Sousa Galdino, A.G.; Kumar, A. Fresh and mechanical properties of concrete made of binary substitution of millet husk ash and wheat straw ash for cement and fine aggregate. J. Mater. Res. Technol. 2021, 13, 872-893. [CrossRef]

53. Bheel, N.; Kumar, A.; Shahzaib, J.; Ali, Z.; Ali, M. An Investigation on Fresh and Hardened Properties of Concrete Blended with Rice Husk Ash as Cementitious Ingredient and Coal Bottom Ash as Sand Replacement Material. In Silicon; Springer: Berlin/Heidelberg, Germany, 2021; pp. 1-12.

54. Bheel, N.; Memon, F.A.; Meghwar, S.L. Study of Fresh and Hardened Properties of Concrete Using Cement with Modified Blend of Millet Husk Ash as Secondary Cementitious Material. In Silicon; Springer: Berlin/Heidelberg, Germany, $2020 ;$ pp. 1-12.

55. Keerio, M.A.; Abbasi, S.A.; Kumar, A.; Bheel, N.; ur Rehaman, K.; Tashfeen, M. Effect of silica fume as cementitious material and waste glass as fine aggregate replacement constituent on selected properties of concrete. In Silicon; Springer: Berlin/Heidelberg, Germany, 2020; pp. 1-12.

56. Bheel, N.; Sohu, S.; Awoyera, P.; Kumar, A.; Abbasi, S.A.; Olalusi, O.B. Effect of Wheat Straw Ash on Fresh and Hardened Concrete Reinforced with Jute Fiber. Adv. Civ. Eng. 2021, 2021, 6659125.

57. Collins, F. Inclusion of carbonation during the life cycle of built and recycled concrete: Influence on their carbon footprint. Int. J. Life Cycle Assess. 2010, 15, 549-556. [CrossRef]

58. Turner, L.K.; Collins, F.G. Carbon dioxide equivalent (CO2-e) emissions: A comparison between geopolymer and OPC cement concrete. Constr. Build. Mater. 2013, 43, 125-130. [CrossRef]

59. Kuruscu, A.O.; Girgin, Z.C. Efficiency of Structural Materials in Sustainable Design. J. Civ. Eng. Archit. 2014, 8, $1260-1265$.

60. Jones, R.; Mccarthy, M.; Newlands, M. Fly Ash Route to Low Embodied $\mathrm{CO}_{2}$ and Implications for Concrete Construction. In Proceedings of the World of Coal Ash Conference, Denver, CO, USA, 9 May 2011.

61. Kumar, A.; Bheel, N.; Ahmed, I.; Rizvi, S.H.; Kumar, R.; Jhatial, A.A. Effect of silica fume and fly ash as cementitious material on hardened properties and embodied carbon of roller compacted concrete. In Environmental Science and Pollution Research; Springer: Berlin/Heidelberg, Germany, 2021; pp. 1-13. 
62. Bheel, N.; Ali, M.O.A.; Khahro, S.H.; Keerio, M.A. Experimental study on fresh, mechanical properties and embodied carbon of concrete blended with sugarcane bagasse ash, metakaolin, and millet husk ash as ternary cementitious material. In Environmental Science and Pollution Research; Springer: Berlin/Heidelberg, Germany, 2021; pp. 1-16.

63. Alnahhal, M.F.; Alengaram, U.J.; Jumaat, M.Z.; Abutaha, F.; Alqedra, M.A.; Nayaka, R.R. Assessment on engineering properties and $\mathrm{CO} 2$ emissions of recycled aggregate concrete incorporating waste products as supplements to Portland cement. J. Clean. Prod. 2018, 203, 822-835. [CrossRef]

64. García-Segura, T.; Yepes, V.; Alcalá, J. Life cycle greenhouse gas emissions of blended cement concrete including carbonation and durability. Int. J. Life Cycle Assess. 2014, 19, 3-12. [CrossRef] 